\title{
Flora da Bahia: Calophyllaceae
}

\section{Amanda Pricilla Batista Santos ${ }^{*}$, Fabio da Silva do Espírito Santo \& Alessandro Rapini ${ }^{\mathrm{b}}$}

Programa de Pós-graduação em Botânica, Departamento de Ciências Biológicas, Universidade Estadual de Feira de Santana, Feira de Santana, Bahia, Brasil.

Resumo - É apresentado aqui o tratamento taxonômico de Calophyllaceae para o estado da Bahia, Brasil. São reconhecidos quatro gêneros e 21 espécies: Calophyllum (C. brasiliense), Caraipa (C. densifolia), Kielmeyera (18 espécies) e Mammea (M. americana), das quais sete espécies são endêmicas do estado. São apresentadas chaves de identificação para os gêneros e espécies, descrições, comentários taxonômicos, ilustrações e mapas de distribuição geográfica das espécies no estado.

Palavras-chave adicionais: florística, Kielmeyera, Nordeste do Brasil, taxonomia.

\begin{abstract}
Flora of Bahia: Calophyllaceae) - The taxonomic treatment of the Calophyllaceae from Bahia state, Brazil, is presented here. Four genera and 21 species are recognized: Calophyllum (C. brasiliense), Caraipa (C. densifolia), Kielmeyera (18 species) and Mammea (M. americana), of which seven species are endemic to the state. Identification keys to genera and species, descriptions, taxonomic comments, illustrations and maps of geographic distribution of species in the state are presented.

Additional keywords: floristics, Kielmeyera, Northeast Brazil, taxonomy.
\end{abstract}

\section{CALOPHYLLACEAE}

Árvores, arbustos, raramente lianas, latescentes, monoicas, poligâmicas ou dioicas. Folhas alternas ou opostas, simples, sem estípulas, margem inteira. Flores mono ou diclinas, actinomorfas, diclamídeas ou raramente monoclamídeas (4-12 tépalas), prefloração imbricada ou convoluta; cálice (2-)4- ou 5-mero, dialissépalo, raramente com sépalas conadas na base; corola (2-)4- ou 5(-12)-mera, dialipétala; androceu com 10 a numerosos estames, conados na base dos filetes, ocasionalmente livres e epipétalos, estaminódios às vezes presentes; anteras rimosas, basifixas ou dorsifixas; ovário súpero, 1-4-carpelar (numerosos apenas em Clusiella), (1)2-5-locular, uni ou pluriovulado; placentação axial ou parietal; disco nectarífero geralmente ausente, estilete comumente alongado. Frutos capsulares, drupas ou bagas; sementes aladas ou não, sem arilo.

Calophyllaceae possui 14 gêneros, cerca de 460 espécies e apresenta distribuição pantropical (Stevens 2001 em diante). No Brasil, ocorrem oito gêneros e aproximadamente 80 espécies, das quais cerca de $73 \%$ são endêmicas (Souza \& Lorenzi 2012; Bittrich et al. 2015) e 13 são apontadas como raras (Bittrich \& Rodrigues 2009). Para a Bahia, foram registrados quatro gêneros: Caraipa, Calophyllum e Mammea, representados por apenas uma espécie cada, e Kielmeyera com 18 espécies. Destas, sete possuem ocorrência restrita ao estado.

A família foi segregada de Clusiaceae s.l. por não constituírem juntas um grupo monofilético. Dentre as

\footnotetext{
*Autora para correspondência: amanda.pricilla@ hotmail.com;

${ }^{\mathrm{a}}$ fse.santo@yahoo.com.br; ${ }^{\mathrm{b}}$ rapinibot@yahoo.com.br

Editor responsável: Pedro Fiaschi

Submetido: 5 ago. 2015; aceito: $11 \mathrm{dez} .2015$

Publicacão eletrônica: 18 dez. 2015: versão final: 28 dez. 2015
}

clusioides (Malpighiales), Calophyllaceae está mais relacionada com o clado composto por Podostemaceae e Hypericaceae, enquanto Clusiaceae s.s. parece estar mais relacionada com Bonnetiaceae (Xi et al. 2012).

\section{Chave para gêneros}

1. Folhas alternas; frutos capsulares.

2. Plantas com tricomas estrelados; sépalas conadas na base; sementes 1-3 por lóculo ...........

2. Caraipa

2'. Plantas glabras ou com tricomas simples, bífidos ou dendrítricos; sépalas livres; numerosas (mais de 3) sementes por lóculo

3. Kielmeyera

1'. Folhas opostas; frutos tipo baga ou drupa.

3. Folhas com nervuras secundárias paralelas; frutos tipo drupa, com uma semente

1. Calophyllum

3'. Folhas com nervuras secundárias reticuladas; frutos tipo baga, com 2-4(8) sementes

4. Mammea (naturalizado)

\section{Calophyllum $\mathrm{L}$.}

Árvores, raramente arbustos; ramos glabrescentes a glabros. Folhas opostas, decussadas; lâmina coriácea a subcoriácea, venações secundária e terciária paralelas, densamente arranjadas. Inflorescências cimosas, axilares ou terminais. Flores monoclinas ou raramente diclinas. Sépalas 2 ou 4, oblongas, largamente elípticas, ovadas, obovadas ou orbiculares, petaloides. Pétalas 2-8, geralmente elípticas a orbiculares, brancas a amareladas. Estames numerosos; anteras sem glândula. Ovário unicarpelar, unilocular, uniovulado; estigma peltado, radial ou irregularmente lobado, raramente infundibuliforme. Drupas globosas a subglobosas, verdes. Semente 1, globosa, sem alas.

Calophyllum é o maior gênero da família, com cerca de 190 espécies (Stevens 2001 em diante). Está 
distribuído, em sua maioria, no Velho Mundo; cerca de 10 espécies, apenas, ocorrem no Novo Mundo (Stevens 2007; Díaz 2013). Pode ser encontrado do México ao Paraguai, no Brasil e nas Ilhas do Caribe (Woodson et al. 1980; D’Arcy 1987; Díaz 2013). No Brasil, ocorrem quatro espécies, mas apenas $C$. brasiliense é registrada para a Bahia (Díaz 2013; Bittrich et al. 2015).

1.1. Calophyllum brasiliense Cambess., Fl. Bras. Merid. (quarto ed.) 1: 320; pl. 67. 1825 [1828]. Figuras 1, 3A-G e 15A-C; Engler (1888: tab. 80).

Nomes populares: carvalho, guanandi, landi.

Árvore ou arbusto, até $20 \mathrm{~m}$ alt.; ramos glabros ou com tricomas esparsos; látex branco a amarelado. Folhas com pecíolo 0,7-1,8 cm compr., canaliculado; lâmina 5-22 × 2,5-6,5 cm, oblonga, elíptica, obovada ou ovada, base cuneada a redonda, ápice agudo, obtuso, redondo, raramente retuso, margem plana, coriácea a cartácea, concolor, nervura principal imersa na face adaxial e proeminente na abaxial, glabra ou ocasionalmente glabrescente, nervuras secundárias ca. $1 \mathrm{~mm}$ distantes entre si; nervuras terciárias imperceptíveis em ambas as faces. Inflorescências cimosas, axilares; pedúnculo 2-4 cm compr., glabro a puberulento; pedicelo 3-9 $\mathrm{mm}$ compr., glabro a puberulento; brácteas e bractéolas 3-5 × 1-1,5 mm, lineares, caducas. Sépalas 2, 3-4 × 1,8-3 mm, ovadas a orbiculares, base e ápice obtusos, brancoesverdeadas, glabras a puberulentas abaxialmente, côncavas, reflexas, petaloides. Pétalas 2 ou 4, 3,5-6× 3-5 mm, brancas, glabras, deflexas. Filetes 1,5-3 mm compr.; anteras ca. $1 \times 1 \mathrm{~mm}$, basifixas. Ovário ca. $2 \times$ 1,5 mm, globoso, glabro; estilete 1,5-2 mm compr., estigma peltado, irregularmente lobado. Drupas 1,5-2,4 $\times 1,7-2,2 \mathrm{~cm}$, globosas. Sementes ca. $2 \times 1,7 \mathrm{~cm}$.

Dentre as espécies de Calophyllum, é a mais frequente na América do Sul, ocorrendo da Colômbia à Bolívia (Díaz 2013). No Brasil, ocorre em diversos estados, nos domínios da Amazônia, Caatinga, Cerrado e Mata Atlântica (Bittrich et al. 2015). D2, D6, D/E9, D10, E2, E6, E/F6, E9, E/F9, E10, F3, F5, F6, F8, F8/9, F/G9, G2, G3, G5, G6, G8/9, H9, I8, I8/9, J8: em restingas e florestas ombrófilas densas na Mata Atlântica, Cerrado e Caatinga, geralmente associada a matas ciliares. Encontrada com flores de setembro a junho e com frutos de setembro a julho.

Material selecionado - Abaíra, 13²19'S, 41º51'W, out. 1993 (fr.), W. Ganev 2364 (HUEFS); Alagoinhas, fev. 2003 (fl.), N.G. Jesus et al. 1693 (ALCB, HRB, HUEFS); Andaraí, 12²4'15"S, 4119'44"S, fev. 1999 (fr.), F. França et al. 2643 (HUEFS, IPA); Aramari, 11 ${ }^{\circ} 58^{\prime} 09^{\prime S} \mathrm{~S}, 38^{\circ} 29^{\prime} 11^{\prime \prime W}$, dez. 2002 (fl.), N.G. Jesus et al.

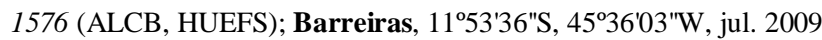
(st.), J. Neri et al. 64 (RB); Belmonte, fev. 1967 (fl.), R.P. Belém \& R.S. Pinheiro 3282 (CEPEC, UB); Caetité, 14 $07^{\prime} 47^{\prime \prime S}, 42^{\circ} 30^{\prime} 15^{\prime \prime} \mathrm{W}$, jan. 2006 (fr.), T.S. Nunes et al. 1608 (HUEFS); Cairu, 13³7'S, $38^{\circ} 55^{\prime} \mathrm{W}$, jan. 2007 (fl.), A.M. Amorim et al. 6767 (CEPEC, HUEFS, HUESC, MBM, RB, UEC); Camaçari, nov. 2006 (fl., fr.), E.P. Queiroz, 2189 (HRB, IBGE, RB); Camamu, 1356'43"S, 38 56'48"W,

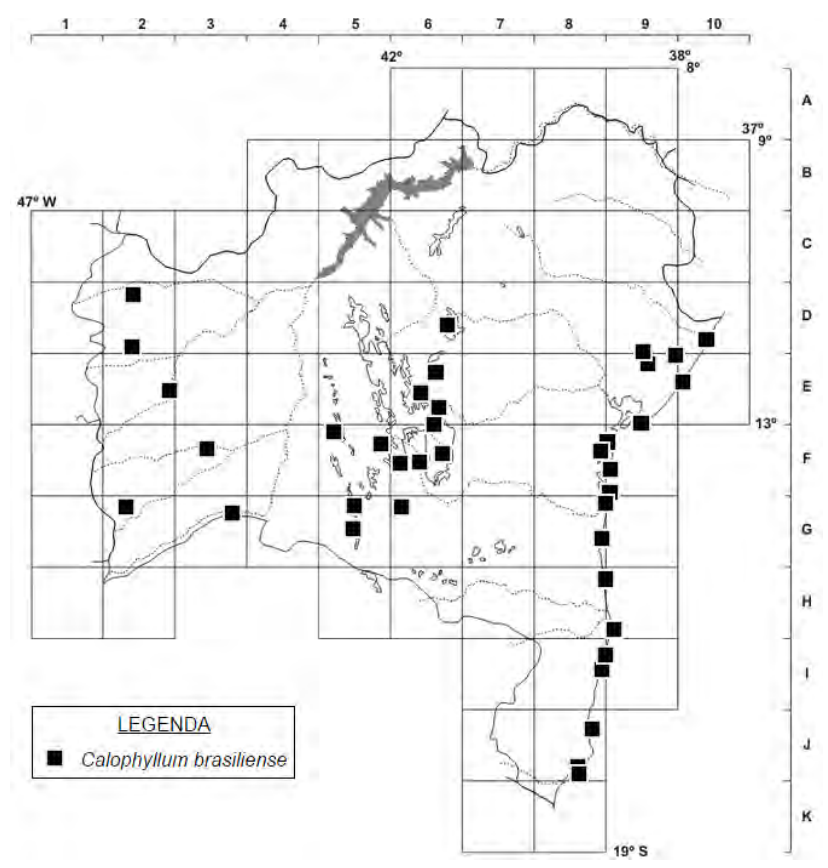

Figura 1. Mapa de distribuição de Calophyllum brasiliense no estado da Bahia.

abr. 2014 (fr.), M.L. Guedes \& I.F. Souza 21898 (ALCB); Caravelas, 17\%47'59"S, 39²3'22"W, dez. 2011 (fl.), E. Matos et al. 1002 (HUEFS); Conde, $11^{\circ} 48^{\prime} \mathrm{S}, 37^{\circ} 36^{\prime} \mathrm{W}$, fev. 2002 (fr.), M.L. Guedes \& D.S. Lima 10125 (ALCB, CEPEC); Correntina, 1319'50"S, 44'33'31"W, jul. 2009 (fr.), J. Neri et al. 67 (RB); Entre Rios, $12^{\circ} 01^{\prime} \mathrm{S}, 38^{\circ} 02^{\prime} \mathrm{W}$, maio 2011 (fr.), A.V. Popovkin \& J.C. Mendes 871

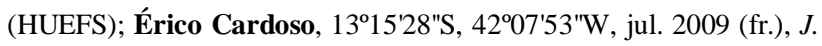

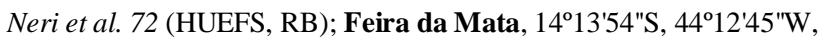
maio 2007 (st.), M.L. Guedes et al. 13482 (ALCB, HUEFS); Formosa do Rio Preto, $11^{\circ} 09^{\prime} 48^{\prime \prime} \mathrm{S}, 45^{\circ} 35^{\prime} 19^{\prime \prime W}$, out. 1989 (fl.), R.C.

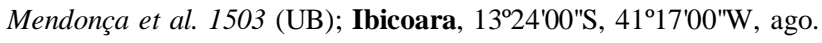
1999 (st.), L.A. Passos Júnior \& M.L. Guedes 285 (ALCB); Ilhéus, 14'35'10"S, 3903'24"W, jun. 2009 (fl., fr.), J. Neri et al. 3 (RB); Jaborandi, $14^{\circ} 08^{\prime} 45^{\prime \prime S}, 45^{\circ} 41^{\prime} 36^{\prime \prime W}$, maio 2001 (fr.), F. França et al. 3728 (ALCB, CEPEC, HRB, HUEFS); Jaguaripe, 1314'18"S, 38 58'42"W, abr. 2012 (fr.), E. Matos 3460 (HUEFS); Jussiape, fev. 1987 (fl.), R.M. Harley et al. 24333 (ALCB, HUEFS); Lençóis,

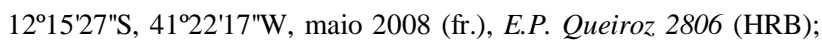
Licínio de Almeida, 14²7'05"S, 42³1'30"W, dez. 2009 (fl.), M.L. Guedes et al. 16746 (ALCB, HUEFS); Macaúbas, 1305'10"S, 42\%47'23"W, jul. 2007 (st.), A.A. Conceição et al. 2471 (HUEFS); Maraú, 14º6'S, 3900'W, out. 2013 (fl.), M.L. Guedes et al. 21104 (ALCB); Mata de São João, 12²3'26"S, 37º55'24"W, mar. 2009 (fr.), M.L. Guedes \& F.S. Gomes 14668 (ALCB); Morro do Chapéu, $11^{\circ} 35 ' 51^{\prime \prime S}, 41^{\circ} 12^{\prime} 42^{\prime \prime W}$, jul. 2011 (fr.), M.L. Guedes \& E. Velloso 18941 (ALCB); Mucugê, 12²5'33"S, 41²3'40"W, dez. 2003 (st.), C.M. Menezes et al. 278 (HRB, MBM); Nova Viçosa, set. 1989 (fr.), A.M. Carvalho et al. 2509 (CEPEC, HUESC, UEC); Palmeiras, $12^{\circ} 32^{\prime} 33^{\prime \prime S}, 41^{\circ} 34^{\prime} 32^{\prime \prime W}$, s.d. (fr.), P.D. Carvalho \& A.A. Conceição 306 (HUEFS); Porto Seguro, 16² $26^{\prime} \mathrm{S}, 3^{\circ} 03^{\prime} \mathrm{W}$, jun. 2012 (fr.), M.L.

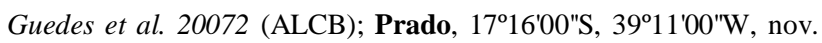
1997 (fl.), M.R. Fonseca \& M.L. Guedes 1094 (ALCB); Rio de Contas, 13³2'S, 41 ${ }^{\circ} 52^{\prime} \mathrm{W}$, abr. 2011 (fr.), M.L. Guedes et al. 18845 (ALCB, MBM); Santa Cruz Cabrália, 16'14'S, 3900'W, nov. 2003 (fl.), M.L. Guedes et al. 10648 (ALCB, CEPEC); São Desidério, $12^{\circ} 30^{\prime} 42^{\prime \prime S}, 45^{\circ} 05^{\prime} 09^{\prime \prime W}$, jul. 2009 (fr.), J. Neri et al. 62 (RB); Una, 
1509'41"S, 3900'04"W, fev. 2014 (fl.), A.P.B. Santos 46 et al. (HUEFS); Valença, maio 2001 (st.), T.S. Santos \& R. Gramacho s.n. (CEPEC 92579, HUEFS 60177, HUESC 5930).

Calophyllum brasiliense pode ser facilmente diferenciada das espécies de Calophyllaceae da Bahia por suas folhas opostas, com nervuras secundárias densamente paralelas, e pelos frutos globosos do tipo drupa.

\section{Caraipa Aubl.}

Árvores ou arbustos; ramos com tricomas estrelados, ocasionalmente com tricomas simples. Folhas alternas; lâmina cartácea a coriácea, venação reticulada, nervuras terciárias perpendiculares às secundárias. Flores monoclinas. Inflorescências terminais ou axilares, em racemos ou panículas. Sépalas 5, coriáceas a subcoriáceas, conadas na base, ápice redondo, obtuso ou agudo, com tricomas estrelados. Pétalas 5, elípticas a assimétricas, alvas a amareladas. Estames numerosos; anteras com glândula dorso-apical. Ovário 3-carpelar, 3-locular, 1-3 óvulos por lóculo; estigma capitado, 3-lobado. Cápsulas septicidas, piramidais, ovoides ou fusiformes, lenhosas, marrons a ferrugíneas. Sementes 1-3 por lóculo, largamente elípticas, aladas.

Caraipa possui cerca de 30 espécies, distribuídas em formações florestais úmidas e savanas arbustivas, principalmente nas regiões da Bacia Amazônica e das Guianas, com espécies também encontradas nos Andes tropicais ( $C$. andina Aymard \& L.M.Campb.) e no Centro-Oeste e Nordeste do Brasil ( $C$. densifolia Mart. subsp. densifolia) (Ewan 1951; Gustafsson et al. 2002; Stevens 2007). No território brasileiro, ocorrem 22 espécies, sendo que apenas $C$. densifolia estende-se até o Cerrado e a Mata Atlântica nos estados de Alagoas, Bahia, Goiás, Pernambuco e Sergipe (Bittrich et al. 2015).

2.1. Caraipa densifolia Mart., Nov. Gen. Sp. Pl. 1: 105; pl. 65, f. 6-11. 1824.

Figuras 2, 3H-N e 15D, E; Wawra (1886: tab. 66).

Nome popular: camaçari.

Árvore, até $20 \mathrm{~m}$ alt.; ramos pubescentes, tricomas estrelados; látex vermelho. Folhas alternas, dísticas; pecíolo 0,4-1,1 cm compr., cilíndrico, puberulento; lâmina 5,5-20,5 × 2,5-5,7 cm, elíptica, oblonga ou obovada, base redonda a cuneada, ápice cuspidado a acuminado, margem plana, coriácea, discolor; face adaxial verde-amarronzada, com nervura principal plana, glabra, as secundárias planas, raramente proeminentes; face abaxial marrom-amarelada, com nervura principal proeminente, as secundárias discretamente proeminentes, com tricomas estrelados esparsos; nervuras terciárias imperceptíveis em ambas as faces. Inflorescências paniculadas, terminais, raramente axilares; pedúnculo 5-13 cm compr., pubescente; pedicelo 3-8 $\mathrm{mm}$ compr., pubescente; brácteas e bractéolas 1,5-3,5 × 0,7-1 mm, lanceoladas. Botões florais 4-5 mm compr. Sépalas elípticas, ferrugíneas, margem ciliada, pubescentes, conadas na base, lobos 1,5-2 × 1-1,5 mm, ápice obtuso. Pétalas 6-8 × 3-4 $\mathrm{mm}$, brancas, margem ciliada, pubescentes, reflexas. Filetes 5-7 mm compr.; anteras ca. 0,6 × 0,4 mm, dorsifixas, glândula cupular. Ovário ca. 1,5 × $2 \mathrm{~mm}$, deltoide, tomentoso; estilete ca. $3 \mathrm{~mm}$ compr., tomentoso, estigma capitado. Cápsulas 1,7-2,2 $\times$ 1,5-1,8 cm, ovoides, oblíquas, lisas e tomentulosas; [sementes não vistas].

Ocorre no Peru, Colômbia, Venezuela, Guiana, Suriname, Guiana Francesa e Brasil. No Brasil, é encontrada na Amazônia, Cerrado e Mata Atlântica, em florestas ciliares e litorâneas (Kubitzki 1978; Bittrich et al. 2015). D10, D/E10, E9/10, E/F8, F8/9, G8, G8/9, H8/9, H9, I8/9, J8: Mata Atlântica, em florestas ombrófilas abertas, restingas e matas ciliares. Floresce entre agosto e março e pode ser encontrada com frutos praticamente o ano todo.

Material selecionado - Belmonte, set. 1970 (fl.), T.S. Santos 1113 (CEPEC, RB); Canavieiras, $15^{\circ} 25^{\prime} 08^{\prime \prime} \mathrm{S}, 38^{\circ} 59^{\prime} 40^{\prime \prime} \mathrm{W}$, out. 2008 (fl.), J.G. Jardim et al. 5423 (HUEFS); Caravelas, mar. 1978 (fl.) S.A. Mori et al. 9677 (CEPEC, RB); Conde, 1202'27"S, 3703'30"W, dez. 1995 (fr.), H.P. Bautista et al. 1751 (HRB, HUESC, RB); Entre Rios, $12^{\circ} 01^{\prime} \mathrm{S}, 38^{\circ} 02^{\prime} \mathrm{W}$, nov. 2010 (fl.), A. Popovkin 781 (HUEFS); Esplanada, 12 $02^{\circ} 36^{\prime \prime} \mathrm{S}, 37^{\circ} 42^{\prime} 35^{\prime \prime} \mathrm{W}$, abr. 1996 (fr.), T. Jost \& H.P. Bautista 268 (HRB, RB); Ihéus, $14^{\circ} 39^{\prime} 13^{\prime \prime S}, 39^{\circ} 04^{\prime} 21^{\prime \prime W}$, set. 2004 (fr.), M.N.S. Stapf et al. 327 (HUEFS); Itacaré, set. 1970 (fl., fr.), T.S. Santos 1069 (CEPEC,

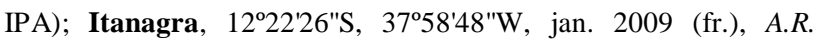
Prates et al. 235 (ALCB); Jaguaripe, 1314'48"S, 3859'02"W, abr. 2012 (fr.), E. Matos 3445 (HUEFS); Jandaíra, 11\%40'11"S, 37³3'37"W, mar. 2012 (fr.), M.L. Guedes \& F.S. Gomes 19388 (ALCB); Porto Seguro, nov. 1983 (fr.), R. Callejas et al. 1715 (CEPEC, MBM); Prado, dez. 1998 (fr.), M.L. Guedes et al. 6355

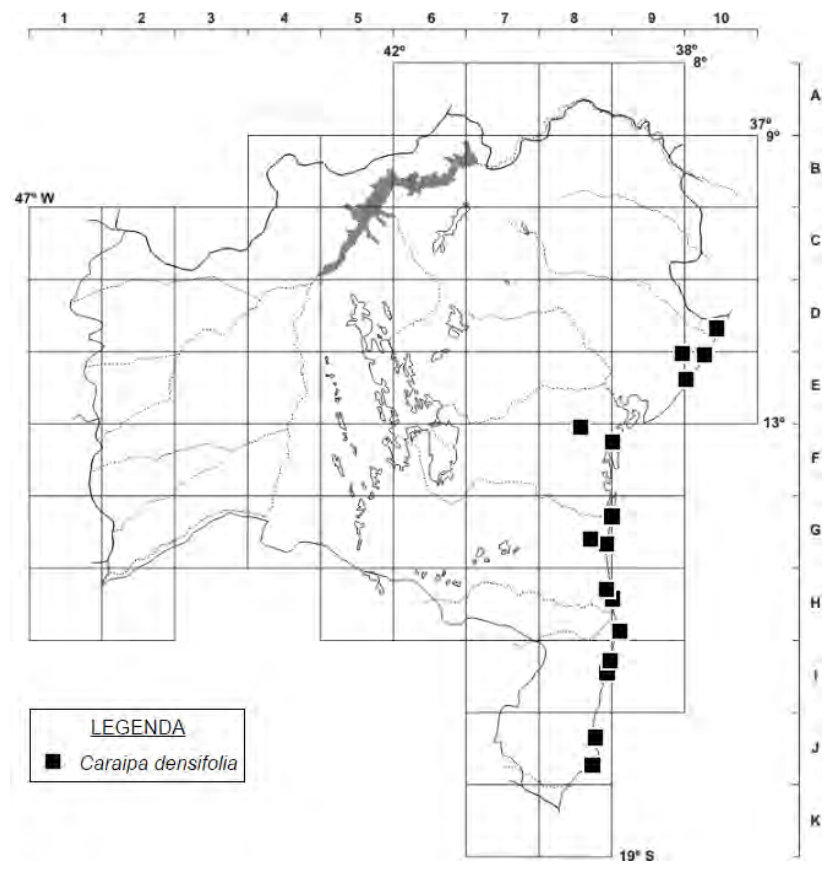

Figura 2. Mapa de distribuição de Caraipa densifolia no estado da Bahia. 


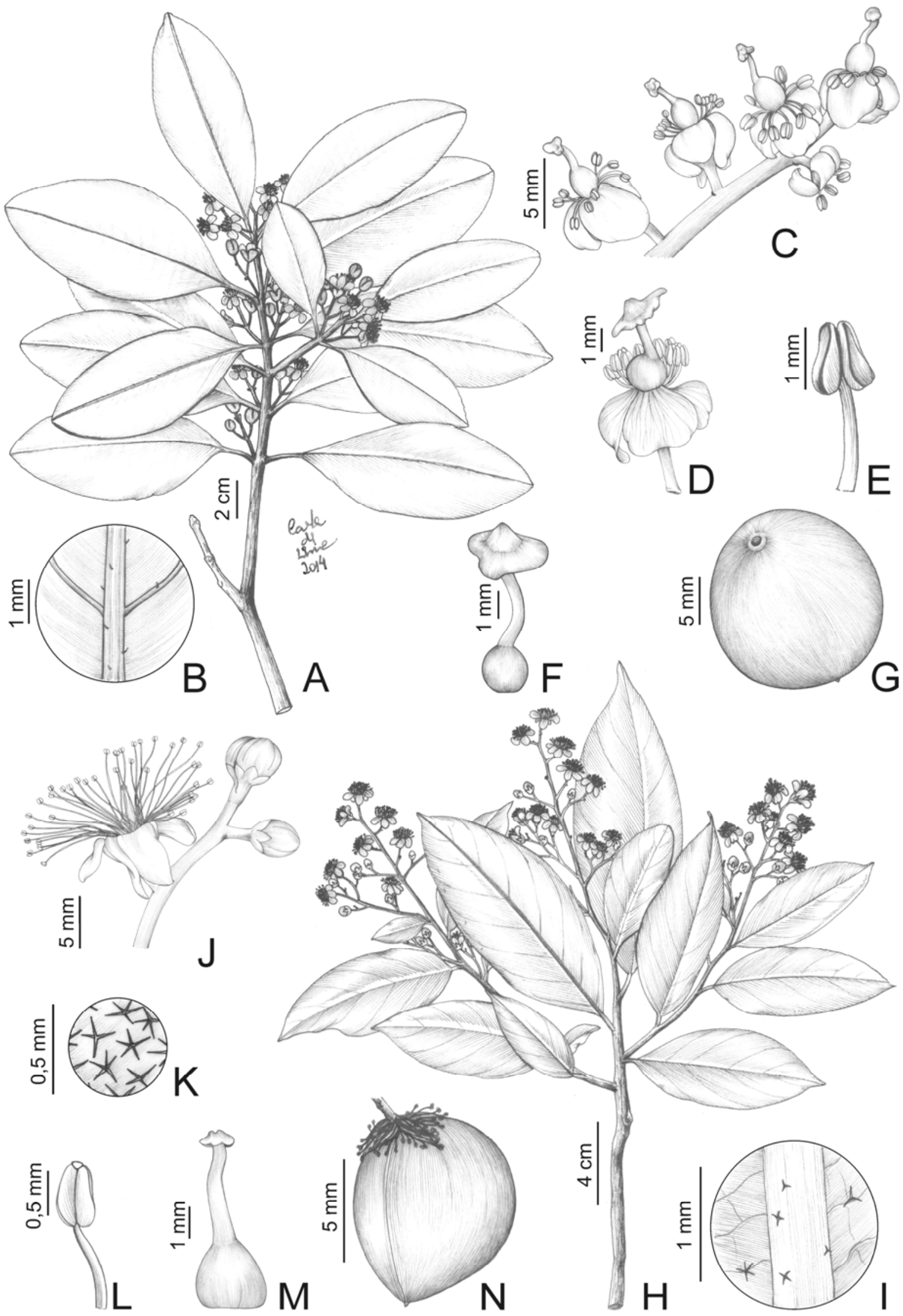

Figura 3. A-G. Calophyllum brasiliense: A- ramo com flores; B- detalhe do indumento da face abaxial das folhas; C- parte da inflorescência; D- flor (parte dos estames removidos); E- estame; F- gineceu; G- fruto imaturo. H-N. Caraipa densifolia: H- ramo com flores; I- detalhe do indumento da face abaxial das folhas; J- detalhe da inflorescência; K- detalhe do indumento das sépalas; L- estame; M- gineceu; N- fruto. (A, C-F- Nascimento 418 HUEFS; B- Carvalho 306 HUEFS; G- Popovkin 871 HUEFS; H, J-M- Popovkin 779 HUEFS; I, N- Matos 742 HUEFS). 
(ALCB, CEPEC); Santa Cruz Cabrália, ago. 1994 (fl.), M.L. Guedes et al. 3643 (ALCB); São Miguel das Matas, 1302'49"S, 39²5'56"W, fev. 2000 (fr.), J.G. Jardim et al. 2890 (ALCB, CEPEC, HRB); Una, out. 2008 (fr.), E.P. Queiroz 3002 (HRB); Uruçuca, maio 1993 (st.), W.W. Thomas et al. 9858 (CEPEC).

$\mathrm{Na}$ Bahia, Caraipa densifolia caracteriza-se pelos botões florais menores que $6 \mathrm{~mm}$ de comprimento, pedúnculo estrelado-pubescente e pelas cápsulas lisas e tomentulosas. Distingue-se também das demais espécies da Bahia pela presença de tricomas estrelados nas sépalas, pétalas, pedicelos, pedúnculo e frutos, além de possuir sépalas conadas na base e cápsulas ovoides e oblíquas. Kubitzki (1978) reconheceu duas subespécies: C. densifolia subsp. densifolia e C. densifolia subsp. rondoniana Kubitzki. Esta última ocorre apenas nos estados do Amazonas, Pará, Rondônia e Mato Grosso (Bittrich et al. 2015) e diferencia-se de C. densifolia subsp. densifolia pelas cápsulas com superfície rugosa e tricomas estrelados esparsos (vs. lisas e tomentulosas).

\section{Kielmeyera Mart. \& Zucc.}

Árvores, arbustos ou subarbustos; ramos glabros ou com tricomas simples, bífidos ou dendrítricos.
Folhas alternas, espiraladas; lâmina membranácea a coriácea, venação reticulada. Inflorescências terminais, em tirsos, corimbos ou raramente flores solitárias; brácteas $8-60 \times 2-10 \mathrm{~mm}$, bractéolas 2-10 $\times 1-8 \mathrm{~mm}$, precocemente caducas. Flores monoclinas ou estaminadas. Sépalas 5, livres, coriáceas a subcoriáceas, glabras ou com tricomas simples, bífidos ou dendrítricos. Pétalas 5, obovadas a assimétricas, alvas a róseas. Estames numerosos; anteras geralmente com glândula apical ou dorso-apical. Ovário 3carpelar, 3-locular, mais de 15 óvulos por lóculo, estigma 3-lobado. Cápsulas septicidas, elípticas a oblongas, lenhosas, marrons a acinzentadas. Sementes numerosas, transversalmente elípticas, com alas laterais.

Kielmeyera é endêmico da América do Sul e inclui 48 espécies (Bittrich et al. 2015). O Brasil é o centro de diversidade do gênero, abrigando 46 espécies, que ocorrem principalmente nos domínios do Cerrado e Mata Atlântica; as outras duas espécies são exclusivas da Bolívia ( $K$. paniculata Rusby) e do Peru ( $K$. peruviana Saddi) (Saddi 1982; Bittrich et al. 2015). Na Bahia, são registradas 18 espécies, das quais sete são endêmicas.

\section{Chave para as espécies}

1. Sépalas com tricomas, margem coriácea.

2. Ovário densamente viloso; sépalas e face abaxial das pétalas com tricomas dendrítricos

3.16. K. rubriflora

2'. Ovário glabro; sépalas e face abaxial das pétalas com tricomas simples.

3. Caule com cortiça; lâmina escrobiculada na face adaxial; nervura principal $2-4,5 \mathrm{~mm}$ larg. na base.

4. Lâmina foliar glabra; nervuras secundárias planas a pouco proeminentes e terciárias imperceptíveis na face abaxial

4'. Lâmina foliar com tricomas na face abaxial; nervuras secundárias e terciárias frequentemente proeminentes na face abaxial

3'. Caule sem cortiça; lâmina lisa na face adaxial; nervura principal $\leq 1 \mathrm{~mm}$ larg. na base.

5. Ramos e folhas glabros; estigma clavado ou subclavado; lâmina foliar estreito-lanceolada a falcada, ápice acuminado

5'. Ramos e face abaxial das folhas com tricomas simples e/ou bífidos ou glabrescentes; estigma capitado; lâmina foliar oblonga, elíptica ou obovada, ápice cuspidado, caudado ou mucronado

1'. Sépalas glabras, margem escariosa.

6. Sépalas oblatas a orbiculares, base auriculada, ápice redondo a obtuso.

7. Inflorescências tirsoides; anteras com glândula apical rostrada.

8. Lâmina coriácea, elíptica, margem sub-revoluta a revoluta; nervuras secundárias formando arcos imperceptíveis na face adaxial

3.11. K. marauensis

8'. Lâmina cartácea a membranácea, obovada, margem plana; nervuras secundárias formando arcos visíveis na face adaxial 3.9. K. itacarensis

7'. Inflorescências corimbosas; anteras com glândula dorso-apical cupular a oblata e punctada.

9. Glândula da antera inconspícua; nervuras secundárias imersas na face adaxial; pecíolo até $2 \mathrm{~cm}$ compr. 3.4. K. bifaria

9'. Glândula da antera conspícua; nervuras planas a proeminentes na face adaxial; pecíolo 1,5-4,5 cm compr.

10. Nervuras secundárias planas a pouco proeminentes na face adaxial; nervuras terciárias pouco visíveis a imperceptíveis na face adaxial

10'. Nervuras secundárias fortemente proeminentes na face adaxial; nervuras terciárias visíveis na face adaxial 3.10. K. lathrophyton

6'. Sépalas ovadas a oblongas, base obtusa, ápice obtuso a agudo. 
11. Pecíolo adaxialmente plano.

12. Lâmina com nervuras secundárias imersas na face adaxial; anteras sem glândulas 3.15. K. reticulata

12'. Lâmina com nervuras secundárias planas a proeminentes na face adaxial; anteras com glândulas.

13. Lâmina com margem revoluta, cutícula acinzentada, nervuras secundárias e terciárias proeminentes na face adaxial (in sicco); anteras com glândulas punctiformes em toda a superfície

3.3. K. argentea

13'. Lâmina com margem plana, desprovida de cutícula, nervuras secundárias e terciárias planas na face adaxial (in sicco); anteras com glândula apical, rostrada

3.17. K. rugosa

11'. Pecíolo adaxialmente canaliculado.

14. Tronco e ramos ferrugíneos; folhas com nervuras secundárias 8-20 mm distantes entre si; anteras sem glândulas

3.8. K. ferruginosa

14'. Tronco e ramos acinzentados; folhas com nervuras secundárias 1-5 mm distantes entre si; anteras com glândula apical.

15'. Nervuras secundárias planas a imersas na face adaxial e imperceptíveis na face abaxial, 1-2 $\mathrm{mm}$ distantes entre si.

16. Lâmina com margem revoluta

3.7. K. elata

16'. Lâmina com margem plana

3.2. K. albopunctata

15. Nervuras secundárias proeminentes na face adaxial e visíveis na face abaxial, $1-5 \mathrm{~mm}$ distantes entre si.

17. Lâmina membranácea; sépalas com larguras subiguais, as internas 4,5-7 larg; glândula da antera globosa 3.13. K. occhioniana

17'. Lâmina coriácea; sépalas com larguras desiguais, as internas 9-12 mm larg.; glândula das anteras rostrada

3.12. K. neglecta

3.1. Kielmeyera abdita Saddi, Kew Bull. 42(1): 221. 1987.

Figuras 4, 8A, 14A e 15F, G; Saddi (1987: fig. 1).

Arbusto ou subarbusto, até $4 \mathrm{~m}$ alt., frequentemente não ramificado; caule glabro; látex branco-amarelado. Folhas com pecíolo $0,5-1,3 \mathrm{~cm}$ compr., adaxialmente canaliculado; lâmina 8-22 $\times$ $1,5-3 \mathrm{~cm}$, estreito-lanceolada a falcada, base atenuada, ápice acuminado, margem plana, coriácea, concolor, glabra; face adaxial com nervura principal plana (ca. 1 $\mathrm{mm}$ larg. na base), as secundárias planas, pouco visíveis, $2-5 \mathrm{~mm}$ distantes entre si, formando arcos marginais visíveis; face abaxial com nervura principal proeminente, as secundárias planas, imperceptíveis; nervuras terciárias imperceptíveis em ambas as faces. Inflorescências em tirsos de cimeiras 3-floras, laxas; raque $8-20 \mathrm{~cm}$ compr., glabra; pedicelo $7-23 \mathrm{~mm}$ compr., glabro. Sépalas externas 4,5-6 × 2-3 mm, internas 5,5-6 × 3-4,5 mm, estreitamente ovadas a lanceoladas, base obtusa, ápice agudo, margem coriácea e ciliada, verde-amareladas, puberulentas a glabrescentes, tricomas simples. Pétalas 1,7-2,2 $\times$ $1-1,3 \mathrm{~cm}$, brancas a branco-rosadas, margem ciliada, puberulentas. Filetes 5-8 mm compr.; anteras ca. 3,5 $\times$ $0,6 \mathrm{~mm}$, subdorsifixas, glândula dorso-apical globosa. Ovário ca. $6 \times 3 \mathrm{~mm}$, elíptico, glabro; estilete ca. 6 mm compr., estigma clavado a subclavado. Cápsulas 7,5-11 × 3-3,5 cm; [sementes não vistas].

Ocorre no Pará, Distrito Federal, Goiás, Mato Grosso, Minas Gerais e Bahia, nos domínios do Cerrado, Amazônia e Caatinga (Bittrich et al. 2015). Considerada endêmica do Brasil, nesse estudo tem sua distribuição ampliada para a Bolívia. D1, D6, E2/3,
E6, F3, F5/6, F6, G5: cerrados e campos rupestres. Floresce de novembro a fevereiro e frutifica entre fevereiro e junho.

Material selecionado - Abaíra, 13º' $17^{\prime} \mathrm{S}, 4^{\circ}{ }^{\circ} 53^{\prime} \mathrm{W}$, jan. 1993 (fl.), W. Ganev 1779 (HUEFS); Barreiras, 1209'10"S, 4459'24"W, abr. 1966 (fr.), H.S. Irwin et al. 14851 (UB); Caetité, 1407'S, 42 $29^{\prime} \mathrm{W}$, abr. 1980 (fr.), R.M. Harley 21118 (CEPEC); Correntina, jul. 1992 (fr.), M.A. Silva et al. 1448 (IBGE); Érico Cardoso,

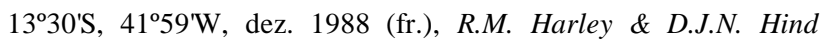

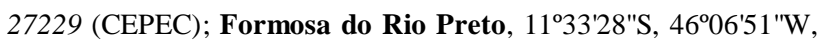
fev. 2000 (fr.), L.C.L. Lima et al. 8 (CEPEC, HUEFS); Morro do

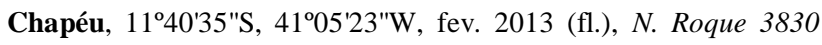
(ALCB); Mucugê, 1310'54"S, 41'32'17"W, dez. 2007 (fl.), $M$. Ibraim et al. 51 (HUEFS); Palmeiras, $12^{\circ} 41^{\prime} \mathrm{S}, 41^{\circ} 31^{\prime} \mathrm{W}$, jan. 2013 (fl.), A.A. Conceição \& F.F. Moreira 4206 (HUEFS); Piatã, $13^{\circ} 04^{\prime} \mathrm{S}, 41^{\circ} 48^{\prime} \mathrm{W}$, abr. 2011 (fr.), M.L. Guedes et al. 18877 (ALCB); Rio de Contas, nov. 1996 (fl.), D.J.N. Hind et al. PCD 4421 (ALCB); Tapiramutá, $11^{\circ} 54^{\prime} 35^{\prime \prime S}, 41^{\circ} 08^{\prime 2} 29^{\prime \prime}$, jun. 2005 (fr.), D.S. Carneiro-Torres et al. 582 (HUEFS).

Material adicional - BOLÍVIA. SANTA CRUZ: Chiquitos, $18^{\circ} 17^{\prime} 13^{\prime \prime S}, 59^{\circ} 37^{\prime} 35^{\prime \prime W}, 876 \mathrm{~m}$ alt., out. 2007 (fl.), J.R.I. Wood et al. 23688 (UB).

Kielmeyera abdita caracteriza-se por ser um arbusto geralmente não ramificado, com folhas estreitolanceoladas e pecíolo de até $1,3 \mathrm{~cm}$ de comprimento. Assemelha-se a $K$. neriifolia, espécie distribuída nos estados de Minas Gerais e Goiás e que, segundo Saddi (1982), é sempre ramificada e apresenta pecíolo maior que $1,5 \mathrm{~cm}$ de comprimento. Saddi (1982) reconheceu K. abdita var. linearifolia Saddi por possuir folhas com $1-1,3 \mathrm{~cm}$ de largura, enquanto $K$. abdita var. abdita possui folhas $\leq 1,5 \mathrm{~cm}$ de largura. Na Bahia, ocorre apenas a variedade típica. 
3.2. Kielmeyera albopunctata Saddi, Rodriguésia 36(60): 61. 1984.

Figuras 4, 14B, C e 15H, I.

Nome popular: visga-nariz.

Árvore, até $18 \mathrm{~m}$ alt., glabra; tronco e ramos acinzentados; látex amarelado. Folhas com pecíolo 0,7-1,9 cm compr., adaxialmente canaliculado; lâmina 5-13,5 × 3-6 cm, elíptica, oblonga a obovada, base cuneada, ápice obtuso a redondo, margem plana, coriácea, discolor; face adaxial verde-oliva, com nervura principal imersa (ca. $0,5 \mathrm{~mm}$ larg. na base), as secundárias imersas ou planas, visíveis a imperceptíveis, 1-2 $\mathrm{mm}$ distantes entre si; face abaxial verde-pálida a amarelada, com nervura principal proeminente, as secundárias planas e imperceptíveis; nervuras terciárias imperceptíveis em ambas as faces. Inflorescências em tirsos de cimeiras 1-3-floras; raque 6,5-12 cm compr.; pedicelo 4-15 $\mathrm{mm}$ compr. Sépalas externas 4-7,5 × 3,5-5,5 mm, internas 6-9,5 × 5-7 mm, ovadas, base obtusa, ápice obtuso, margem escariosa, verdes, glabras. Pétalas 2,5-3,1 × 1,7-2 cm, brancas, glabras. Filetes 5-11 mm compr.; anteras ca. $3 \times 1 \mathrm{~mm}$, subdorsifixas, glândula apical globosa a rostrada. Ovário ca. $5 \times 3$ $\mathrm{mm}$, elíptico; estilete ca. $5 \mathrm{~mm}$ compr., estigma capitado. Cápsulas ca. $7 \times 2,5 \mathrm{~cm}$; sementes com núcleo seminífero ca. $0,9 \times 1,5 \mathrm{~cm}$ e alas ca. $1,5 \mathrm{~cm}$ compr.

Distribuída na Mata Atlântica da Bahia e Espírito Santo (Bittrich et al. 2015). D9/10, D10, F6, F7, F/G7, G6, H8, I8/9: Mata Atlântica, em restingas, matas de cipó, florestas estacionais semideciduais, florestas estacionais deciduais, e raramente em campos rupestres. Floresce de janeiro a abril e frutifica de abril a setembro.

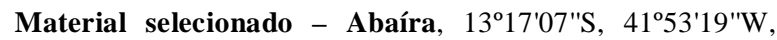
mar. 2005 (fl.), M.L. Guedes et al. 11471 (ALCB, MBM); Boa Nova, 1803'29"S, 4252'59"W, mar. 2013 (fl.), L.Y.S. Aona et al. 2160 (HUEFS, RB); Brumado, set. 2009 (fr.), C. Correia 502 (HUEFS); Camacan, 15²3'30"S, 39³3'55"W, ago. 2008 (fl., fr.), A.M. Amorim et al. 7685 (CEPEC); Itatim/Santa Teresinha, abr. 1958 (fl.), R.P. Lordêlo 24/58 (ALCB); Itiruçu, abr. 1999 (fl.), A.M. Amorim et al. 2756 (CEPEC); Jandaíra, 11³9'59"S, $37^{\circ} 29^{\prime} 01^{\prime \prime W}$, abr. 2004 (fl.), T. Jost et al. 641 (ALCB, HRB, HUEFS); Jequié, 1353'27"S, 4007'20"W, abr. 2007 (fr.), L.P. Queiroz et al. 12954 (HUEFS); Mata de São João, 11²7'24"S, 3757'10"W, jan. 2004 (fl.), M.C. Ferreira \& G.E.L. Macedo 1297 (HUEFS, UEC); Porto Seguro, fev. 1970 (fl.), J.A. Jesus 616 (CEPEC, RB); Santa Cruz Cabrália, jan. 1972 (fl.) A. Eupunino 174 (CEPEC).

Kielmeyera albopunctata caracteriza-se pelas folhas com nervuras secundárias pouco visíveis a imperceptíveis na face adaxial, bem como pelas sépalas internas com dimensões semelhantes às externas. É morfologicamente próxima a $K$. neglecta, diferindo-se desta pelas sépalas internas mais estreitas (5-7 mm vs. 9-12 mm) e pelas nervuras secundárias da face adaxial imersas ou planas in sicco (vs. proeminentes).

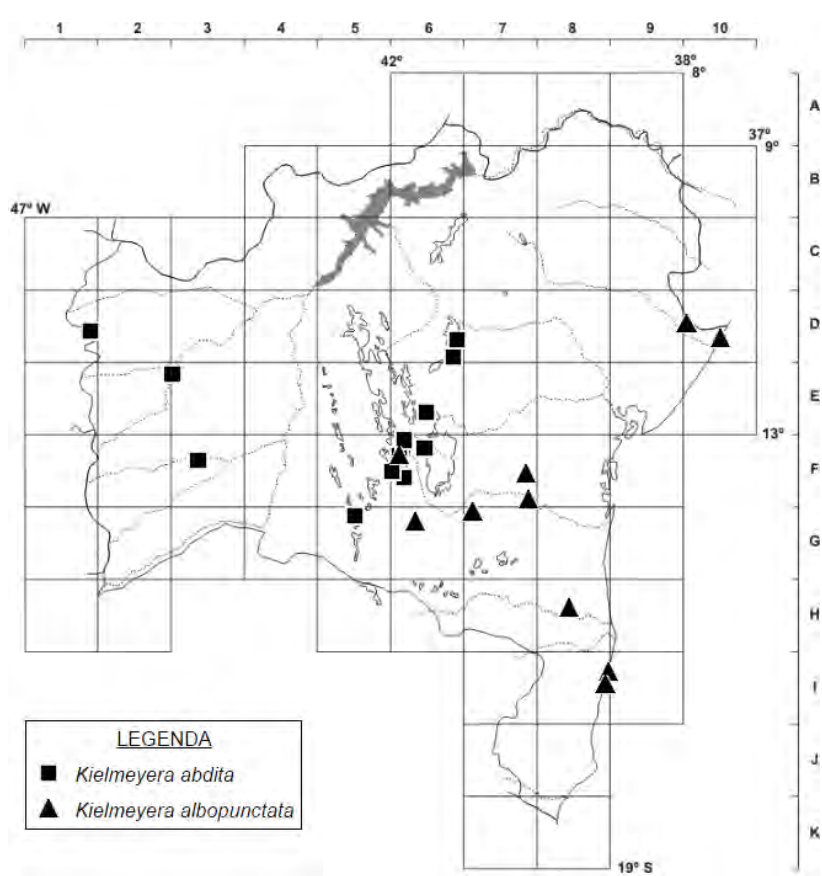

Figura 4. Mapa de distribuição de Kielmeyera abdita e K. albopunctata no estado da Bahia.

3.3. Kielmeyera argentea Choisy, Mém. Soc. Phys. Genève 14: 163. 1855.

Figuras 5, 13A-G e 16A, B.

Nomes populares: leiteira, pau-santo.

Arbusto ou subarbusto, até $3 \mathrm{~m}$ alt., cespitoso, glabro; tronco e ramos acinzentados; látex brancoamarelado. Folhas com pecíolo 0,3-1,2 cm compr., adaxialmente plano; lâmina 2,5-10,5 × 2-4,5 cm, obovada a elíptica, base cuneada a atenuada, ápice retuso ou raramente obtuso, margem revoluta, coriácea, discolor; face adaxial verde-amarronzada, coberta por cutícula acinzentada, com nervura principal plana a proeminente (ca. $1 \mathrm{~mm}$ larg. na base), as secundárias proeminentes, ca. $1 \mathrm{~mm}$ distantes entre si, nervuras terciárias proeminentes, densamente reticuladas; face abaxial marrom, com nervura principal proeminente, as secundárias e terciárias planas e pouco visíveis. Inflorescências em tirsos de cimeiras 1-3-floras; raque 6-8 cm compr.; pedicelo 5-15 $\mathrm{mm}$ compr. Sépalas externas 3-4 × 3-4 mm, internas 4-6 × 4-5 mm, ovadas, base e ápice obtusos, margem escariosa, verdes, glabras. Pétalas 2,5-2,8 $\times 0,9-1,4 \mathrm{~cm}$, brancas, glabras. Filetes 7-10 mm compr.; anteras ca. $2 \times 0,7$ $\mathrm{mm}$, subdorsifixas, glândulas punctiformes em toda superfície. Ovário ca. $6 \times 4 \mathrm{~mm}$, elíptico; estilete ca. 8 $\mathrm{mm}$, estigma capitado. Cápsulas 6-13 × 3-4,5 cm; sementes com núcleo seminífero ca. $0,6 \times 0,7 \mathrm{~cm}$ e alas ca. $1,8 \mathrm{~cm}$ compr.

Endêmica das restingas do estado da Bahia (Saddi 1982). E9, F8/9: Mata Atlântica, em restingas arbustivas. Pode ser encontrada com flores e frutos durante o ano todo.

Material selecionado - Alagoinhas, $12^{\circ} 04^{\prime} 11^{\prime \prime} \mathrm{S}, 38^{\circ} 20^{\prime} 09^{\prime \prime} \mathrm{W}$, abr. 2010 (fl.), E. Melo et al. 8027 (HUEFS); Cairu, ago. 1994 (fr.), 
M.L. Guedes et al. s.n. (ALCB 26046); Lauro de Freitas, set. 1998 (fr.), C.B. Costa 315 (ALCB); Salvador, 12 ${ }^{\circ} 55^{\prime} 07^{\prime \prime S}, 38^{\circ} 19^{\prime} 07^{\prime \prime} \mathrm{W}$, out. 2013 (fr.), A.P.B. Santos et al. 44 (HUEFS).

Kielmeyera argentea caracteriza-se pelo hábito cespitoso, pelas folhas com cutícula acinzentada e nervuras secundárias e terciárias proeminentes, densamente reticuladas na face adaxial (in sicco). Assemelha-se a K. rugosa, da qual difere pela margem foliar revoluta (vs. plana), pelas nervuras secundárias e terciárias proeminentes (vs. planas), quando secas e pelas glândulas das anteras punctiformes (vs. rostrada). Assemelha-se também a $K$. reticulata, diferindo pelo porte menor ( $\leq 3 \mathrm{~m}$ vs. $>3 \mathrm{~m}$ alt.), pelas nervuras secundárias proeminentes na face adaxial (vs. imersas) e pelas glândulas punctiformes nas anteras (vs. anteras sem glândulas).

\subsection{Kielmeyera bifaria Saddi, Kew Bull. 42: 223.} 1987.

Figuras 5 e 14D; Saddi (1987: fig. 2).

Arbusto ou arvoreta, até $5 \mathrm{~m}$ alt., glabro; látex branco a amarelado. Folhas com pecíolo $0,8-2 \mathrm{~cm}$ compr., adaxialmente canaliculado; lâmina 4,5-10,5 × 2,5-5,5 cm, elíptica, base cuneada, ápice redondo a retuso, margem plana, coriácea, concolor; face adaxial com nervura principal imersa (base $<1 \mathrm{~mm}$ larg.) e secundárias imersas; face abaxial com nervura principal proeminente e secundárias planas e imperceptíveis, 2-4 $\mathrm{mm}$ distantes entre si; nervuras terciárias imperceptíveis em ambas as faces. Inflorescências corimbosas com cimeiras 1- ou 2floras; raque 5,5-8 cm compr.; pedicelo 5-10 mm compr. Sépalas externas 6-8 × 7,5-9 mm, internas 8-11 × 10-12 mm, orbiculares a oblatas, base auriculada, ápice redondo a obtuso, margem escariosa, verdes, glabras. Pétalas 3-3,2 × 1,8-2,3 cm, brancas, glabras. Filetes 6-8 mm compr.; anteras ca. $2 \times 1 \mathrm{~mm}$, subdorsifixas, glândula dorso-apical oblata, punctada, inconspícua. Ovário ca. $7 \times 4,5 \mathrm{~mm}$, elíptico a oblongo; estilete ca. $9 \mathrm{~mm}$ compr., estigma capitado. Cápsulas (imaturas) ca. 7,5 × 2,3 cm; [sementes não vistas].

Ocorre na Bahia e Minas Gerais, em áreas de cerrado, sendo frequente em florestas de galeria (Saddi 1982; Bittrich et al. 2015). F6: cerrados, campos rupestres e matas ciliares. Encontrada com flores entre outubro e janeiro e com frutos em março.

Material selecionado - Barra da Estiva, 13\%41'03"S, 4117'55"W, out. 2009 (fl.), M.L. Guedes \& F.S. Gomes 16711

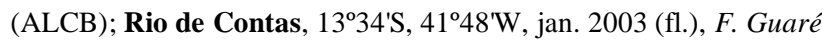
s.n. (ALCB 61581).

Kielmeyera bifaria assemelha-se a $K$. petiolaris e $K$. lathrophyton devido às sépalas oblatas a orbiculares, mas difere de ambas pelas folhas com nervuras secundárias imersas na face adaxial (vs. planas a proeminentes) e pecíolo geralmente mais curto (até 2 cm vs. 1,5-4,5 cm compr.).
3.5. Kielmeyera coriacea Mart. \& Zucc., Flora 8(2): 30. 1825.

Figuras 5, 8B, C e 16C; Martius (1824: tab. 70).

Nomes populares: bastão-menino-de-deus, pau-santo, pau-de-sangue.

Árvore ou arbusto, até $8 \mathrm{~m}$ alt.; caule com cortiça; ramos glabros a tomentosos no ápice, tricomas simples; látex amarelo. Folhas sésseis ou pecioladas; pecíolo 0,1-1 cm compr., adaxialmente plano; lâmina 6,5-20 × 2,5-8,5 cm, oblonga, oblanceolada, elíptica, obovada a largamente obovada, base cuneada a atenuada, ápice obtuso, retuso ou agudo, margem plana, coriácea, discolor; face adaxial verde-clara a amarronzada, glabra, escrobiculada, com nervura principal plana (2-4 mm larg. na base), as secundárias planas, 3-8 $\mathrm{mm}$ distantes entre si; face abaxial marrom, glabra, com nervura principal proeminente, as secundárias planas a pouco proeminentes, glabra; nervuras terciárias imperceptíveis em ambas as faces. Inflorescências em tirsos de cimeiras unifloras, contraídos; raque 5-7 cm compr., glabra a glabrescente; pedicelo 14-20 mm compr., tomentoso ou tomentuloso. Sépalas externas 4-7 × 3-5 mm, internas 5-9 × 4,5-6 mm, ovadas, base obtusa, ápice subagudo, margem coriácea e ciliada, verdes, tomentosas a tomentulosas. Pétalas 2,3-2,4 × 1,2-1,3 $\mathrm{cm}$, brancas a róseas, margem coriácea, ciliada, tomentosas. Filetes 6-10 mm compr.; anteras ca. $3 \times$ $0,9 \mathrm{~mm}$, subdorsifixas, glândula dorso-apical globosa. Ovário ca. $5 \times 3 \mathrm{~mm}$, elíptico, glabro; estilete $6-8 \mathrm{~mm}$ compr., estigma clavado. Cápsulas 9-14 × 3,5-4,5 $\mathrm{cm}$; sementes com núcleo seminífero ca. $1,4 \times 1,9 \mathrm{~cm} \mathrm{e}$ alas ca. 1,4 cm compr.

Amplamente distribuída no Paraguai e Brasil, onde é encontrada no Cerrado, Amazônia, Caatinga e Mata Atlântica (Saddi 1982; Bittrich et al. 2015). D1, D2, E2, E6, F1, F1/2, F6, G2, G5: cerrados e campos rupestres, ocorrendo em simpatria com $K$. tomentosa, espécie mais semelhante morfologicamente. Floresce de outubro a fevereiro e frutifica de fevereiro a novembro.

Material selecionado - Andaraí, abr. 2011 (fr.), D.L. Santana et al. 180 (ALCB, CEPEC); Barreiras, $11^{\circ} 53^{\prime} 41^{\prime \prime S}, 45^{\circ} 36^{\prime} 03^{\prime \prime} \mathrm{W}$, fev. 2010 (fr.), L. Passos et al. 373 (CEPEC, HUEFS, HUESC); Caetité, abr. 2003 (fr.), M.L. Guedes et al. 10340 (CEPEC); Cocos, 14³7'46"S, 4503'57"W, mar. 2010 (fr.), K. Yoshida-Arns et al. in BHRG 652 (UFP); Coribe, jul. 1998 (st.), S. Bridgewater et al. 1013 (UB); Correntina, 133' $59^{\prime \prime S}, 45^{\circ} 58^{\prime} 09^{\prime \prime W}$, ago. 2013 (fr.), G. Felitto et al. 678 (MBM); Formosa do Rio Preto, 11 $27^{\circ} 21^{\prime \prime S}$, 461' $45^{\prime \prime W}$, fev. 2000 (fr.), N.G. Jesus et al. 825 (CEN, CEPEC, HRB, HUEFS, RB); Luís Eduardo Magalhães, $12^{\circ} 13^{\prime} \mathrm{S}, 45^{\circ} 49^{\prime} \mathrm{W}$, nov. 2011 (fl., fr.), M.L. Guedes et al. 17883 (ALCB, MBM);

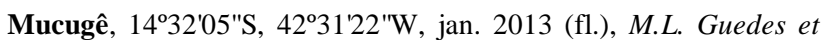
al. 20331 (HST); Piatã, fev. 2006 (fl.), F. Guaré s.n. (ALCB 75126); São Desidério, $12^{\circ} 50^{\prime} 31^{\prime \prime} \mathrm{S}, 4^{\circ} 28^{\prime} 18^{\prime \prime} \mathrm{W}$, abr. 2011 (fr.), E.P. Queiroz 4835 (HRB).

Kielmeyera coriacea caracteriza-se pelas folhas com face adaxial escrobiculada, pecíolo até $1 \mathrm{~cm}$ de 


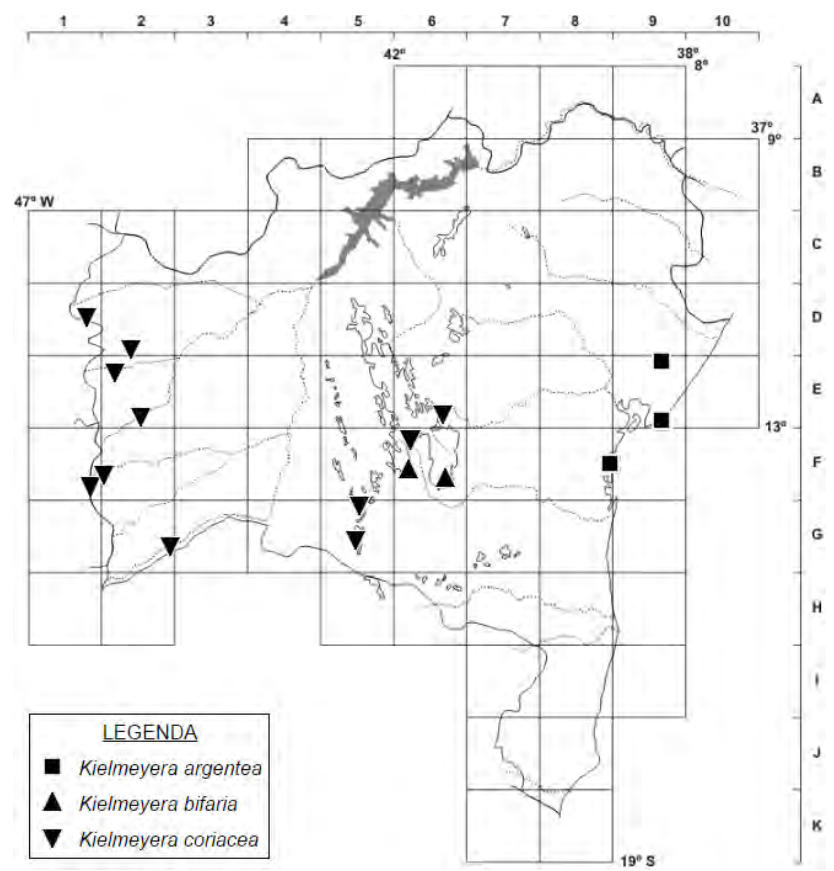

Figura 5. Mapa de distribuição de Kielmeyera argentea, K. bifaria e $K$. coriacea no estado da Bahia.

comprimento, pela nervura central com $2-4 \mathrm{~mm}$ de largura na base e nervuras secundárias pouco visíveis em ambas as faces. É comumente confundida com $K$. tomentosa, distinguindo-se pelas folhas glabras (vs. tomentosas a tomentulosas abaxialmente) e pelas nervuras secundárias e terciárias planas abaxialmente (vs. proeminentes).

\subsection{Kielmeyera cuspidata Saddi, Kew Bull. 39(4):} 732. 1984.

Figuras 6, 8D, E, 14E, F e 16D-F; Saddi (1984: fig. 1).

Arbusto, até $3 \mathrm{~m}$ alt.; ramos castanhos com tricomas simples ou bífidos esparsos ou puberulentos; látex branco a amarelado. Folhas com pecíolo 0,8-3,6 cm compr., adaxialmente canaliculado, glabro, ocasionalmente com tricomas simples ou bífidos esparsos; lâmina 2,5-10,5 × 1-4 cm, oblonga, elíptica ou obovada, base cuneada, ápice cuspidado, caudado ou mucronado, margem plana, ciliada, cartácea, discolor; face adaxial verde-escura a verdeamarronzada, glabra, com nervura principal plana $(\leq 1$ $\mathrm{mm}$ larg. na base); face abaxial verde-pálida, glabrescentes ou com tricomas simples ou bífidos esparsos, com nervura principal proeminente; nervuras secundárias planas, imperceptíveis, ca. $1 \mathrm{~mm}$ distantes entre si; nervuras terciárias imperceptíveis em ambas as faces. Inflorescências em cimeiras contraídas, 1-5floras; raque 1,5-6 cm compr., tomentulosa; pedicelo 6-14 mm compr., pubescente. Sépalas externas 5-6 $\times$ 3-3,5 mm, internas 5,5-8 × 3,5-4 mm, elípticas a ovadas, base obtusa, ápice agudo a acuminado, margem coriácea e ciliada, castanho-esverdeadas a vináceas, pubescentes. Pétalas 3,2-4,5 × 1,6-2,8 cm, brancas a branco-esverdeadas, com mancha vinácea e pubescentes abaxialmente. Filetes 9-11 mm compr.; anteras ca. $2 \times 1 \mathrm{~mm}$, dorsifixas, retrorsas, glândulas punctiformes em toda superfície. Ovário ca. 2,5 × 1,3 $\mathrm{mm}$, elíptico a ovado, glabro; estilete 3-4 mm compr., estigma capitado. Cápsulas ca. $6,5 \times 2 \mathrm{~cm}$; [sementes não vistas].

Endêmica da Bahia. E6, F6: campos rupestres da Chapada Diamantina. Floresce de janeiro a outubro e frutifica de outubro a julho.

Material selecionado - Abaíra, 13²18'S, 4151'W, jan. 1994 (fl.), W. Ganev 2834 (HUEFS); Andaraí, 1248'15"S, 41²0'28"W, fev. 2009 (fl.), M.L. Guedes et al. 14592 (ALCB); Ibicoara, $13^{\circ} 17^{\prime} \mathrm{S}, 41^{\circ} 21^{\prime} \mathrm{W}$, mar. 2005 (fl.), R. Funch \& L.S. Funch 757

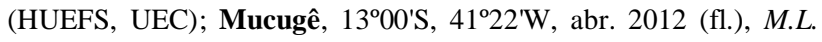

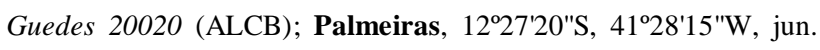
1997 (fl.), M.L. Guedes 5143 (ALCB).

Kielmeyera cuspidata é facilmente distinta das demais espécies do gênero no estado pelo ápice foliar cuspidado e pela presença de tricomas bífidos e simples nos ramos, folhas e sépalas, além das sépalas castanho-esverdeadas a vináceas.

3.7. Kielmeyera elata Saddi, Bradea 4(5): 28. 1984. Figuras 6, 8F, G, 14G e 16G-I.

Nome popular: cajueiro.

Árvore, até $15 \mathrm{~m}$ alt., glabra; tronco e ramos acinzentados; látex amarelo translúcido. Folhas com pecíolo 0,9-2,3 cm compr., adaxialmente canaliculado; lâmina 8-23 × 3-7 cm, oblonga-obovada a elípticaobovada, base cuneada, ápice obtuso a retuso, margem revoluta, coriácea, concolor, verde-amareladas; face adaxial com nervura principal imersa (ca. $1 \mathrm{~mm}$ larg. na base), secundárias planas e visíveis; face abaxial com nervura principal plana, secundárias planas, imperceptíveis, paralelas, 1-2 mm distantes entre si, as terciárias imperceptíveis. Inflorescências em tirsos de cimeiras 1-3-floras; raque 7-18 cm compr.; pedicelo 8-20 mm compr. Sépalas externas 5-6 × 4-6 mm, internas 8-11 ×6,5-8 mm, ovadas, base obtusa, ápice subagudo, margem escariosa, verdes, glabras. Pétalas 3-3,5 × 1,5-2 cm, brancas, glabras. Filetes 8-12 mm compr.; anteras ca. $2 \times 0,7 \mathrm{~mm}$, subdorsifixas, glândula apical globosa. Ovário ca. $7 \times 4 \mathrm{~mm}$, oblongo a ovado; estilete 2-4 mm compr., estigma capitado. Cápsulas ca. $12 \times 4 \mathrm{~cm}$; [sementes não vistas].

Endêmica da Bahia. E9, G8, H8/9, H9, I8/9: Mata Atlântica, em restingas e tabuleiros. Encontrada com flores entre janeiro e maio e com frutos de julho a novembro.

Material selecionado - Belmonte, abr. 1975 (fl.), T.S. Santos 2979 (CEPEC); Ilhéus, nov. 1980 (fr.), L.A.M. Silva et al. 1235 (CEPEC); Porto Seguro, out. 2005 (fr.), L.J. Alves 62 (ALCB); Santa Cruz Cabrália, 16²19'S, 3901'W, mar. 1974 (fl.), R.M. Harley et al. 17138 (CEPEC, HUEFS, RB); Una, maio 1965 (fl.), R.P. Belém \& M. Magalhães 1044 (holótipo RB!, isótipos CEPEC!, RB!, UB!).

Kielmeyera elata assemelha-se morfologicamente a $K$. neglecta e $K$. albopunctata. No entanto, difere de 
ambas pelas folhas de margem revoluta (vs. plana) e nervuras secundárias mais adensadas que naquelas espécies.

\subsection{Kielmeyera ferruginosa A.B.Santos \& R.J.Trad,} Phytotaxa 221(3): 289. 2015.

Figuras 6, 8H e 17A, B.

Árvore, até $20 \mathrm{~m}$ alt., glabra; caule e ramos ferrugíneos, descamando-se em lâminas delgadas; látex laranja. Folhas com pecíolo 1,7-3,5 cm compr., adaxialmente canaliculado; lâmina 17,5-28,7 $\times$ 5,8-10,5 cm, elíptica-obovada, ápice obtuso a retuso, base cuneada, margem revoluta, coriácea, concolor; face adaxial com nervura principal imersa (ca. 1,5 mm larg. na base), secundárias proeminentes, 8-20 $\mathrm{mm}$ distantes entre si; face abaxial com nervuras principal e secundárias proeminentes; nervuras terciárias discretamente proeminentes em ambas as faces. Inflorescências em tirsos de cimeiras 1-3-floras; raque 22-34 cm compr.; pedicelo 5-7 mm compr. Sépalas externas 6-9 × 4,5-8 mm, internas 8-10 × 7,5-10 mm, ovadas, base e ápice obtusos, margem escariosa, verdes, glabras. Pétalas 4-4,5 × 1,5-2,2 cm, brancas, glabras. Filetes 6-12 mm compr.; anteras ca. $2 \times 1$ mm, subdorsifixas, glândulas ausentes. Ovário ca. 10 $\times 7 \mathrm{~mm}$, ovoide; estilete 4-7 mm compr., estigma capitado. Cápsulas 14-15 × 4-4,5 cm; sementes com núcleo seminífero ca. $2 \times 2,5 \mathrm{~cm}$ e alas ca. $3 \mathrm{~cm}$ compr.

Endêmica da Mata Atlântica da Bahia. H8/9: restingas arbóreas alagáveis. Encontrada com flores de novembro a abril e com frutos de outubro a abril.

Material selecionado - Una, $15^{\circ} 08^{\prime} 06^{\prime \prime} \mathrm{S}$, 3900 $00^{\prime} 06^{\prime \prime} \mathrm{W}$, abr. 2014 (fl.), R.J. Trad et al. 136 (holótipo UEC!, isótipos HUEFS!, RB!); id. (fr.), R.J. Trad et al. 137 (parátipo UEC!).

Kielmeyera ferruginosa caracteriza-se por possuir tronco e ramos ferrugíneos, látex laranja, folhas amarelo-alaranjadas (in sicco) e nervuras secundárias mais distantes entre si que nas demais espécies encontradas no estado (8-20 vs. 1-8 mm).

3.9. Kielmeyera itacarensis Saddi, Bradea 4(42): 341. 1987.

Figura 7.

Árvore, até $10 \mathrm{~m}$ alt., glabra; látex amarelado.

Folhas com pecíolo 1,6-3,5 cm compr., adaxialmente canaliculado; lâmina 11-23 × 3,5-7 cm, obovada, base subatenuada, ápice obtuso, margem plana, cartácea a membranácea, discolor; face adaxial verde-escura, com nervura principal imersa $(<1 \mathrm{~mm}$ larg. na base), as secundárias proeminentes, $3-5 \mathrm{~mm}$ distantes entre si, formando arcos visíveis; face abaxial verde-pálida a amarelada, com nervura principal proeminente, as secundárias planas a pouco proeminentes; nervuras terciárias pouco visíveis em ambas as faces. Inflorescências em tirsos de cimeiras 3-floras; raque 7-9 cm compr.; pedicelo 5-9 $\mathrm{mm}$. Sépalas externas 6-7 × 7-10 mm, internas 8-10 × 7-11 mm, oblatas,

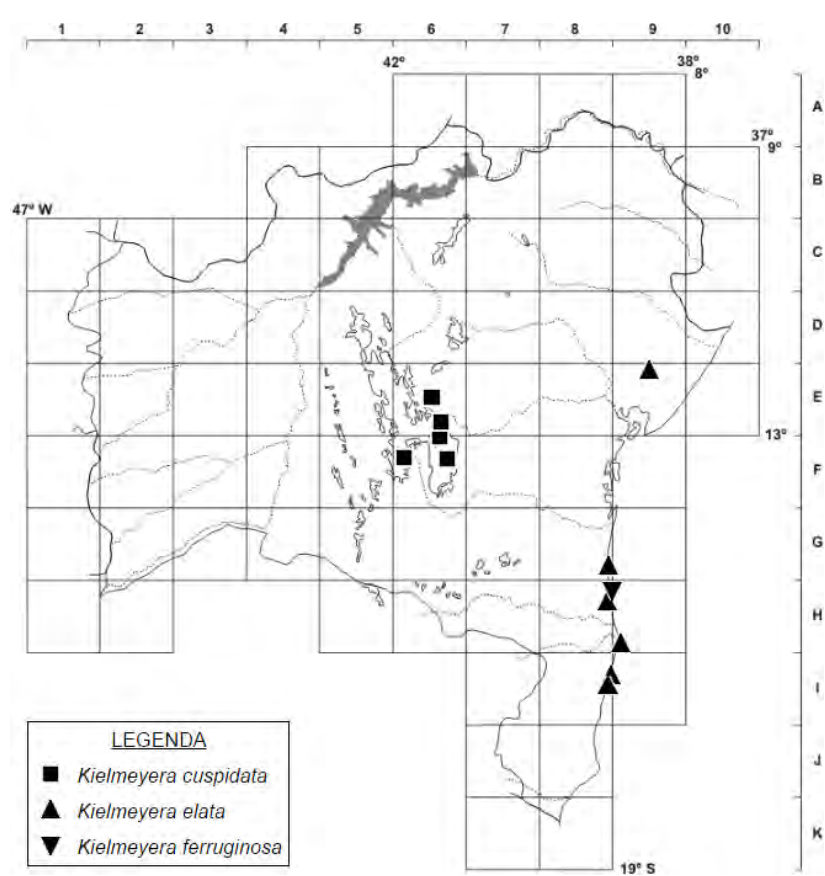

Figura 6. Mapa de distribuição de Kielmeyera cuspidata, K. elata e $K$. ferruginosa no estado da Bahia.

ápice redondo, base obtusa a auriculada, margem escariosa, verde-claras, glabras. Pétalas (em botão) brancas, glabras; anteras ca. $3 \times 1 \mathrm{~mm}$, subdorsifixas, glândula apical rostrada. [Ovário, cápsulas e sementes não vistos].

Endêmica da Bahia, conhecida apenas pela coleçãotipo. G8/9: Mata Atlântica, em mata ciliar. Encontrada com flores em janeiro.

Material examinado - Itacaré, jan. 1977 (fl.), R.M. Harley et al. 18340 (holótipo RB!, isótipo CEPEC!).

Kielmeyera itacarensis caracteriza-se pelas sépalas oblatas e folhas cartáceas de base subatenuada. Assemelha-se a $K$. marauensis, da qual difere pelas folhas cartáceas (vs. coriáceas), obovadas (vs. elípticas), com margem plana (vs. subrevoluta) e pelas nervuras secundárias formando arcos visíveis (vs. imperceptíveis). A descrição das pétalas e anteras foi retirada de Saddi (1982).

3.10. Kielmeyera lathrophyton Saddi, Kew Bull. 42(1): 225.1987.

Figuras 7, 8I, 14H, I e 17C; Saddi (1987: fig. 3).

Nome popular: pau-santo.

Arbusto a árvore, até $8 \mathrm{~m}$ alt., glabro; látex branco a amarelado. Folhas com pecíolo 1,8-4,5 cm compr., adaxialmente canaliculado; lâmina 7-13 × 3,5-6,5 cm, oblonga, elíptica ou ovada, base cuneada a redonda, ápice obtuso, redondo ou retuso, margem plana, cartácea, discolor; face adaxial verde-oliva, com nervura principal imersa $(<1 \mathrm{~mm}$ larg. na base), as secundárias fortemente proeminentes, 2-5 $\mathrm{mm}$ distantes entre si; face abaxial verde-pálida, com nervura principal proeminente, as secundárias planas a pouco proeminentes; nervuras terciárias visíveis em ambas as faces. Inflorescências corimbosas em 


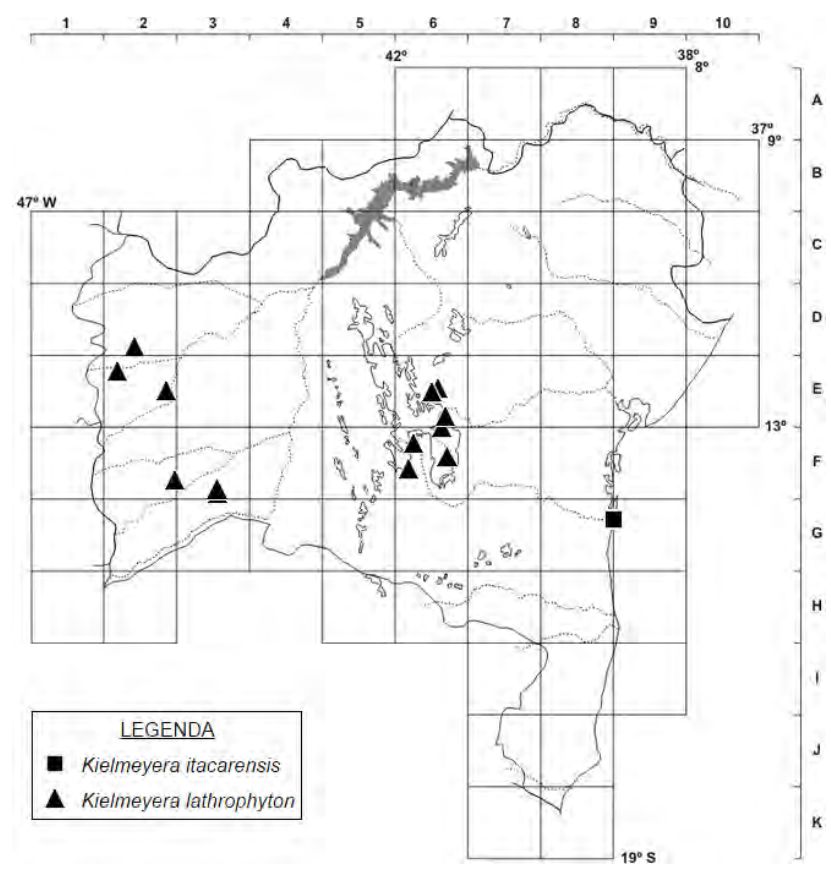

Figura 7. Mapa de distribuição de Kielmeyera itacarensis e $K$. lathrophyton no estado da Bahia.

cimeiras 1-3-floras; raque 5-8 cm compr.; pedicelo 4-12 mm compr. Sépalas externas 5-7 × 7-10 mm, internas 8-12 × 11-16 mm, orbiculares a oblatas, base auriculada, ápice redondo, margem escariosa, verdeclaras, glabras. Pétalas 3,2-3,7 × 2,4-2,7 cm, brancas, glabras. Filetes 6-12 mm compr.; anteras ca. $2 \times 1$ mm, subdorsifixas, glândula dorso-apical cupular a oblata, punctada. Ovário ca. $9 \times 4 \mathrm{~mm}$, ovado a elíptico; estilete 6-9 mm compr., estigma capitado. Cápsulas $10-20 \times 3-4,5 \mathrm{~cm}$; sementes com núcleo seminífero ca. $1,2 \times 1,5 \mathrm{~cm}$ e alas ca. $2 \mathrm{~cm}$ compr.

Ocorre no Cerrado, nos estados de Goiás, Minas Gerais, São Paulo, Bahia e no Distrito Federal (Bittrich et al. 2015). D2, E2, E6, E/F6, F2/3, F3, F6: cerrados e campos rupestres. Em alguns municípios do oeste do estado e da Chapada Diamantina ocorre em simpatria com $K$. petiolaris, espécie morfologicamente bastante semelhante. Floresce de agosto a março e pode ser encontrada com frutos de abril a janeiro.

Material selecionado - Andaraí, 120 $51^{\prime} 05^{\prime \prime} \mathrm{S}, 4^{\circ} 18^{\prime} 36^{\prime \prime W}$, dez.

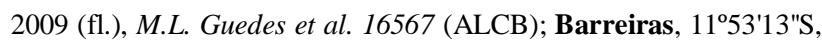
453'22"W, jan. 2004 (fl.), M. Machado \& M. Oliveira 70 (HUEFS); Cocos, 1352'04"S, 44²7'06"W, ago. 2007 (fl., fr.), M.L. Guedes et al. 13705 (ALCB, HUEFS, MBM); Coribe, 1355'56"S, 44²6'52"W, jan. 2008 (fl.), A. Rapini et al. 1435 (HUEFS); Correntina, $13^{\circ} 44^{\prime} \mathrm{S}, 45^{\circ} 2^{\prime} \mathrm{W}$, jan. 2008 (fl.), M.M. Silva-Castro \& I.F. Castro 1400 (HUEFS); Ibicoara, ago. 2011 (fr.), H.A. Ogasawara et al. 145 (ALCB); Lençóis, 12²7'47"S, 4125'07"W, dez. 2009 (fl.), M.L. Guedes et al. 16566 (ALCB); Luís Eduardo Magalhães, 12²13'S, 4549'W, nov. 2010 (fr.), M.L. Guedes et al. 18128 (ALCB); Mucugê,

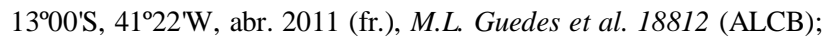
Palmeiras, 12³0'58"S, 41 ${ }^{\circ} 29^{\prime} 40^{\prime \prime} \mathrm{W}$, jan. 2012 (fl), G. Almeida-Silva

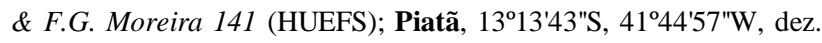
2003 (fl.), N. Roque et al. 929 (ALCB, HRB); Rio de Contas,

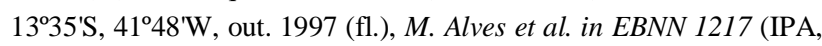

PEUFR); São Desidério, 12³0'01"S, 450ํ'01"W, maio 2010 (fr.), E. Melo et al. 8297 (HUEFS).

Kielmeyera lathrophyton assemelha-se a $K$. petiolaris, diferindo desta pelas nervuras secundárias e terciárias visíveis, proeminentes adaxialmente (vs. pouco visíveis a imperceptíveis, planas a pouco proeminentes). Segundo Saddi (1982), também podem ser distintas com base na textura e forma da lâmina. Entretanto, estes caracteres não se mostraram úteis para a delimitação específica dessas duas espécies na Bahia. Os três caracteres acima citados são bastante variáveis e se sobrepõem, havendo assim um grande número de espécimes intermediários entre essas duas espécies. $\mathrm{O}$ grau de proeminência e visibilidade das nervuras in sicco são as características que mais ajudaram na identificação desses táxons.

3.11. Kielmeyera marauensis Saddi, Kew Bull. 39(4): 737. 1984.

Figuras 9, 11A, 14J, K e 17D-F.

Nome popular: cambone.

Árvore, até $25 \mathrm{~m}$ alt., glabra; tronco e ramos acinzentados; látex amarelado. Folhas com pecíolo 1,3-3,9 cm compr., adaxialmente canaliculado; lâmina 9,5-22,5 × 2,8-7,5 cm, elíptica, base cuneada, ápice obtuso, margem sub-revoluta a revoluta, coriácea, discolor; face adaxial verde-amarronzada, com nervura principal imersa ( $<1 \mathrm{~mm}$ larg. na base), as secundárias proeminentes, 2-5 $\mathrm{mm}$ distantes entre si, formando arcos imperceptíveis; face abaxial marrom, com nervura principal proeminente, as secundárias planas, visíveis ou não; nervuras terciárias imperceptíveis em ambas as faces. Inflorescências em tirsos de cimeiras 1- ou 2-floras; raque 6-13 cm compr.; pedicelo 5-15 $\mathrm{mm}$ compr. Sépalas externas 4-6 × 5-7,5 mm, internas 6-11 × 8-14 mm, oblatas, ápice redondo, base auriculada ou raramente obtusa, margem escariosa, verdes, glabras. Pétalas 3,5-3,8 × 1,9-2,3 cm, brancas, glabras. Filetes 6-13 mm compr.; anteras ca. $2 \times 1$ $\mathrm{mm}$, subdorsifixas, glândula apical rostrada. Ovário ca. $10 \times 6 \mathrm{~mm}$, ovado; estilete 6-7 mm compr., estigma capitado. Cápsulas ca. $16 \times 4,5 \mathrm{~cm}$; [sementes não vistas].

Endêmica da Mata Atlântica da Bahia. F8, F9, G8/9: restingas e florestas ombrófilas densas. Floresce entre janeiro e maio e foi coletada com frutos em setembro.

Material selecionado - Amargosa, $13^{\circ} 05^{\prime} \mathrm{S}, 39^{\circ} 39^{\prime} \mathrm{W}$, jan. 2007 (fl.), D. Cardoso et al. 1664 (CEPEC, HUEFS); Cairu, fev. 1968 (fl.), G. Pinto s.n. (ALCB 8971); Ilhéus, maio 2010 (fl.), L.A.M. Silva et al. 5234 (CEPEC, HUEFS, HUESC, RB); Itacaré, abr. 1989 (fl.), L.A.M. Silva et al. 2701 (CEPEC, UEC, RB); Maraú, abr. 1968 (fl.) R.P. Belém 3664 (CEPEC, UEC); Una, $15^{\circ} 12^{\prime} 50^{\prime \prime S}, 39^{\circ} 02^{\prime} 04^{\prime \prime W}$, fev. 2014 (fl.), A.P.B. Santos et al. 47 (HUEFS); Uruçuca, 14 $20^{\prime} 13^{\prime \prime S}, 39^{\circ} 01^{\prime} 05^{\prime \prime} \mathrm{W}$, fev. 2014 (fl.), A.P.B.

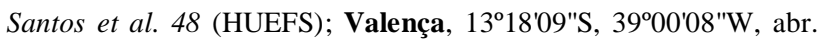
2012 (fl.), E. Matos 3422 (HUEFS); Vera Cruz, 1305'30"S, $38^{\circ} 47^{\prime} 10^{\prime \prime W}$, set. 2011 (fr.), E. Matos et al. 590 (HUEFS). 

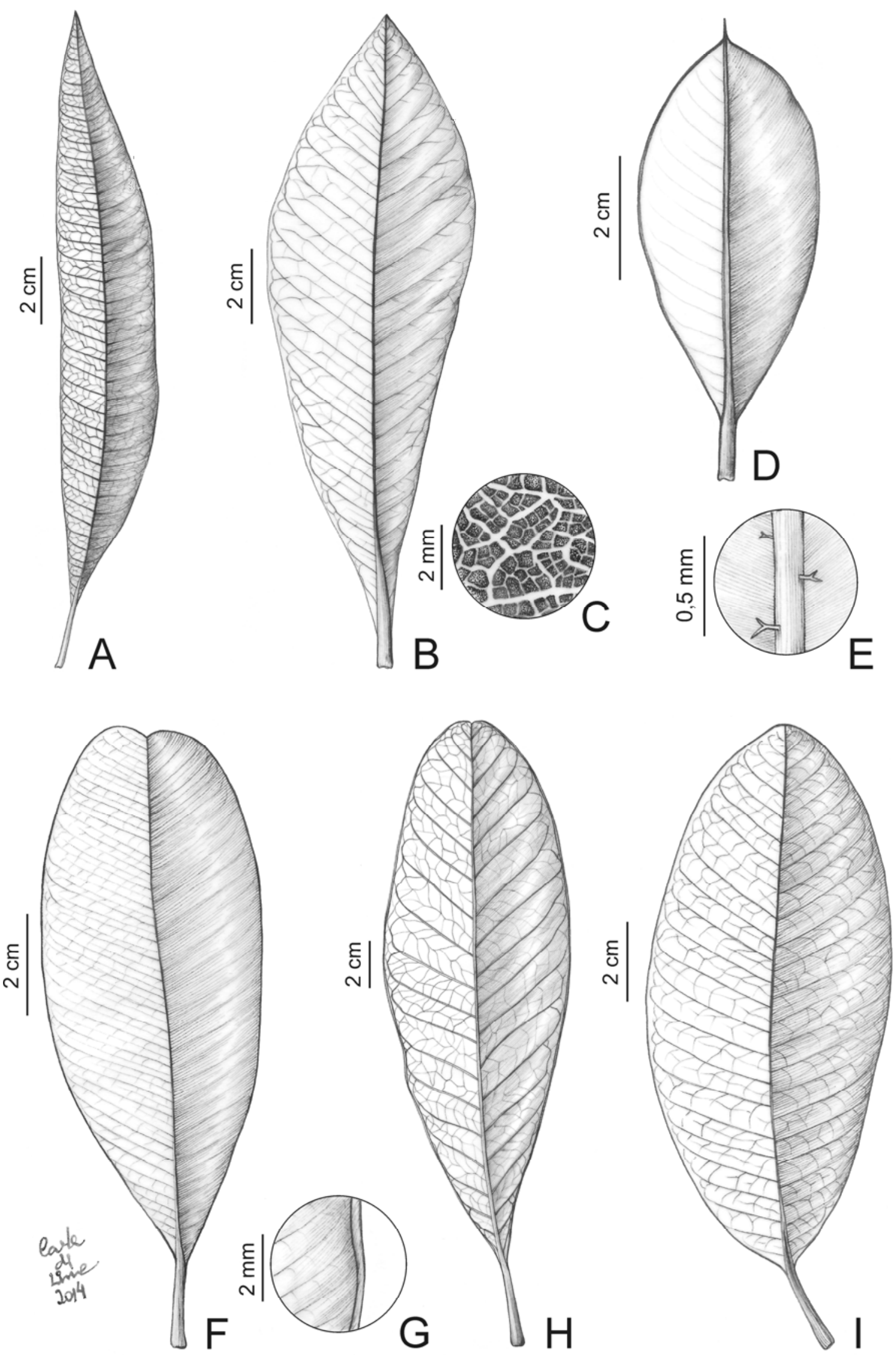

Figura 8. Folhas de Kielmeyera. A. K. abdita: face adaxial. B, C. $K$. coriacea: B- face abaxial; C- detalhe da face adaxial. D, E. K. cuspidata: D- face adaxial; E- detalhe dos tricomas na face abaxial. F, G. K. elata: F-face adaxial; G. detalhe da margem na face abaxial; H. K. ferruginosa: face abaxial; I. K. latrophyton: face adaxial. (A- Harley 50351 HUEFS; B, C- Reis 149 HUEFS; D, E- França 4134 HUEFS; F, G- Santos 54 HUEFS; H- Santos 55 HUEFS; I- Funch 618 HUEFS). 
Kielmeyera marauensis caracteriza-se pelas folhas com nervuras secundárias formando arcos imperceptíveis na margem e pelas sépalas oblatas, com base frequentemente auriculada. Pode ser encontrada em simpatria com $K$. neglecta, com a qual pode ser confundida, distinguindo-se pelas folhas com margem sub-revoluta (vs. plana), nervuras secundárias geralmente mais distantes entre si (2-5 vs. $1-3 \mathrm{~mm}) \mathrm{e}$ imperceptíveis (vs. visíveis) próximo à margem, sépalas oblatas (vs. ovadas) e base frequentemente auriculada (vs. obtusa). Assemelha-se também a $K$. itacarensis, mas pode ser distinguida pelas características já mencionadas naquela espécie.

\subsection{Kielmeyera neglecta Saddi, Kew Bull. 39(4):} 735. 1984.

Figuras 9, 11B e 17G; Saddi (1984: fig. 2).

Nomes populares: cega-bugre, congonha-de-folhaamargosa, pau-santo, remeloso.

Árvore, até $25 \mathrm{~m}$ alt., glabra; tronco e ramos acinzentados; látex branco-amarelado. Folhas com pecíolo 1,4-3,2 cm compr., adaxialmente canaliculado; lâmina 8-22,5 × 4,5-7 cm, oblonga a elíptica, base cuneada, ápice obtuso, raramente retuso, margem plana, coriácea, discolor; face adaxial verde-oliva, com nervura principal imersa (base $<1 \mathrm{~mm}$ larg.), as secundárias proeminentes, às vezes lateralmente enrugadas, 1-3 $\mathrm{mm}$ distantes entre si, as terciárias pouco visíveis; face abaxial verde-pálida ou amarronzada, com nervura principal proeminente, as secundárias planas a pouco proeminente, visíveis, as terciárias imperceptíveis. Inflorescências em tirsos de cimeiras 1-3-floras; raque 6-14 cm compr.; pedicelo 8-12 mm compr. Sépalas externas 4-7,5 × 4-8 mm, internas 7-9 9 9-12 mm, ovadas, base e ápice obtusos, margem escariosa, verdes, glabras. Pétalas 2,8-4 $\times$ 1,5-2 cm, brancas, glabras. Filetes 7-15 mm compr.; anteras ca. $2 \times 0,8 \mathrm{~mm}$, subdorsifixas, glândula apical rostrada. Ovário ca. $9 \times 5 \mathrm{~mm}$, oblongo, elíptico ou ovado; estilete 7-8 $\mathrm{mm}$ compr., estigma capitado. Cápsulas ca. $14,5 \times 5 \mathrm{~cm}$; sementes com núcleo seminífero ca. $1,5 \times 1,8 \mathrm{~cm}$ e alas ca. $3,5 \mathrm{~cm}$ compr.

Considerada endêmica da Mata Atlântica da Bahia (Bittrich et al. 2015), foi registrada também para Alagoas, em restingas. D9/10, D10, E8, E9, E/F9, E10, F8/9, G8/9, H8, I8: restingas, bordas de florestas ombrófilas e matas higrófilas. Floresce entre novembro e junho e frutifica de fevereiro a novembro.

Material selecionado - Acajutiba, $11^{\circ} 43^{\prime} \mathrm{S}, 37^{\circ} 59^{\prime} \mathrm{W}$, ago. 1984 (fr.), J.C.A. Lima \& M.M. Santos 191 (ALCB, CEPEC, HRB, HUEFS, IPA, RB); Alagoinhas, mar. 2006 (fl.), N.G. Jesus et al.

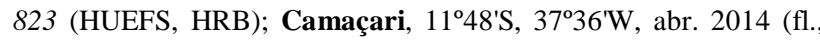
fr.), M.L. Guedes et al. 21553 (ALCB); Conde, 1203'24"S, 37²41'27"W, jan. 1996 (fl.), M.C. Ferreira \& T. Jost 853 (CEPEC, HUEFS, HRB, HUESC, IBGE, IPA, RB); Entre Rios, nov. 2011,

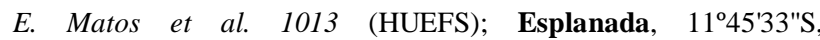
3751'05"W, maio 2000 (fr.), A. Nascimento et al. 263 (ALCB, CEN, CEPEC, HUEFS, HUESC, HRB); Ilhéus, maio 2010 (fl.),
L.A.M. Silva et al. 5234 (CEPEC, HUEFS, HUESC, RB); Jandaíra,

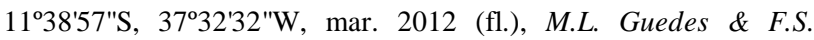
Gomes et al. 19377 (ALCB); Mata de São João, jun. 2012 (fl.), A.M. Miranda et al. 6526 (HST, HUEFS, RB); Porto Seguro, mar. 1972 (fl.), A. Eupunino 249 (CEPEC); Salvador, 1255'38"S, 38'25'38"W, fev. 2008 (fl.), E.P. Queiroz \& P.R.C. Oliveira 2692 (HRB); São Sebastião do Passé, 12³4'52"S, 38²2'45"W, jun. 1999 (fr.), M.L. Guedes 3247 (ALCB); Simões Filho, mar. 2002 (fl., fr.), M.F. Neves et al. 178 (BAH); Una, 1509'S, 3905'W, mar. 1993 (fl.), S.C. Sant'Ana et al. 284 (CEPEC, HRB, MBM); Uruçuca, $14^{\circ} 28^{\prime} 25^{\prime \prime S}, 39^{\circ} 01^{\prime} 54^{\prime \prime} \mathrm{W}$, fev. 2014 (fl., fr.), A.P.B. Santos et al. 49

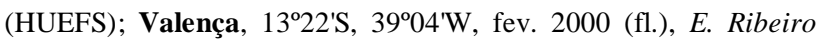
s.n. (ALCB 55233); Vera Cruz, abr. 1999 (fl.), M.L. Guedes et al. s.n. (ALCB 41340).

Material adicional - BRASIL. ALAGOAS: Marechal Deodoro, 0945'38"S, 3550'45"W, ago. 1999 (fr.), R.P.L. Lemos et al. 4213 (ALCB); ib., fev. 2004 (fl.) R.P.L. Lemos 8206 (ALCB, $\mathrm{RB})$.

Kielmeyera neglecta caracteriza-se pelas folhas com nervuras secundárias proeminentes na face adaxial e pelas sépalas ovadas de base obtusa, com as internas mais largas que as externas (9-12 mm vs. 4-8 mm). Assemelha-se a $K$. albopunctata e $K$. marauensis, mas pode ser distinguida destas pelas características apresentadas nos comentários das referidas espécies. Também é morfologicamente relacionada a $K$. occhioniana, da qual é diferenciada pelas folhas coriáceas (vs. cartáceas), sépalas de larguras desiguais (vs. subiguais) e glândula da antera rostrada (vs. globosa).

\subsection{Kielmeyera occhioniana Saddi, Rodriguésia} 36(60): 62. 1984.

Figuras 9 e 11C.

Nome popular: pau-de-leite.

Árvore até 8,5 m alt., glabra; látex amarelado; tronco e ramos acinzentados. Folhas com pecíolo 1,2-2,7 cm compr., adaxialmente canaliculado; lâmina 9-20 × 3,5-8 cm, elíptica a obovada, base cuneada a atenuada, ápice obtuso, margem plana, membranácea, discolor; face adaxial verde-oliva, com nervura principal imersa (ca. 0,5 $\mathrm{mm}$ larg. na base), as secundárias proeminentes, visíveis, 2-5 $\mathrm{mm}$ distantes entre si; face abaxial verde-amarelada, com nervura principal proeminente, as secundárias planas, visíveis; nervuras terciárias imperceptíveis em ambas as faces. Inflorescências em tirsos de cimeiras 1-3-floras, laxas; raque 8-15 cm compr.; pedicelo 3-7 mm compr. Sépalas externas 5-7,5 × 4-5,5 mm, internas 7-8,5× 4,5-7 mm, ovadas, base obtusa, ápice subagudo a agudo, margem escariosa, verdes, glabras. Pétalas (em botão) brancas a branco-rosadas, glabras. Filetes 4-6 mm compr.; anteras ca. 1,5 ×0,8 mm, subdorsifixas, glândula apical globosa. Ovário ca. $7 \times 5 \mathrm{~mm}$; estilete ca. $4 \mathrm{~mm}$ compr., estigma capitado. [Cápsulas e sementes não vistas].

Considerada endêmica das matas de tabuleiro do Espírito Santo e em perigo de extinção (Coelho et al. 
2013), Kielmeyera occhioniana foi registrada pela primeira vez para a Bahia a partir deste estudo, tendo sido incorporada à Lista de Espécies da Flora do Brasil (Bittrich et al. 2015). B/C9, G8, I/J8: Mata Atlântica, em florestas estacionais deciduais e no ecótono entre caatingas e cerrados. Floresce de setembro a fevereiro.

Material selecionado - Itagibá, $14^{\circ} 10^{\prime} 53^{\prime \prime} \mathrm{S}, 39^{\circ} 42^{\prime} 31$ 'W, set. 2009 (fl.), M.L. Guedes et al. 16481 (ALCB); Itamaraju, 1659'26"S, 39³6'11"W, fev. 2007 (fl.), A.M. Amorim et al. 6900 (CEPEC); Jeremoabo, 09 58'00"S, 38²6'00"W, dez. 2009 (fl.), V.S. Almeida \& M.S. Barbosa 31 (HUEFS).

Kielmeyera occhioniana caracteriza-se pelas folhas cartáceas e pelas sépalas internas e externas de larguras semelhantes e ápice subagudo. Assemelha-se a $K$. albopunctata, da qual se distingue pela lâmina cartácea (vs. coriácea), nervuras secundárias mais distantes entre si (2-5 $\mathrm{mm}$ vs. $1-2 \mathrm{~mm})$, proeminentes na face adaxial (vs. planas a imersas) e visíveis na face abaxial (vs. imperceptíveis).

3.14. Kielmeyera petiolaris Mart \& Zucc., Flora 8(2): 30. 1825.

Figuras 10, 11D, 14L e 17H.

Arbusto até $3 \mathrm{~m}$ alt., glabro; látex branco a amarelado. Folhas com pecíolo 1,5-3,6 cm compr., adaxialmente canaliculado; lâmina 6-10,5 × 3-5,5 cm, elíptica a ovada, base cuneada, ápice obtuso, agudo ou raramente retuso, margem plana, cartácea a coriácea, concolor; face adaxial com nervura principal imersa (< $1 \mathrm{~mm}$ larg. na base), as secundárias planas a pouco proeminentes, 1-3 mm distantes entre si; face abaxial com nervura principal proeminente, as secundárias planas; nervuras terciárias pouco visíveis a imperceptíveis em ambas as faces. Inflorescências corimbosas em cimeiras 1-3-floras; raque $4-7 \mathrm{~cm}$

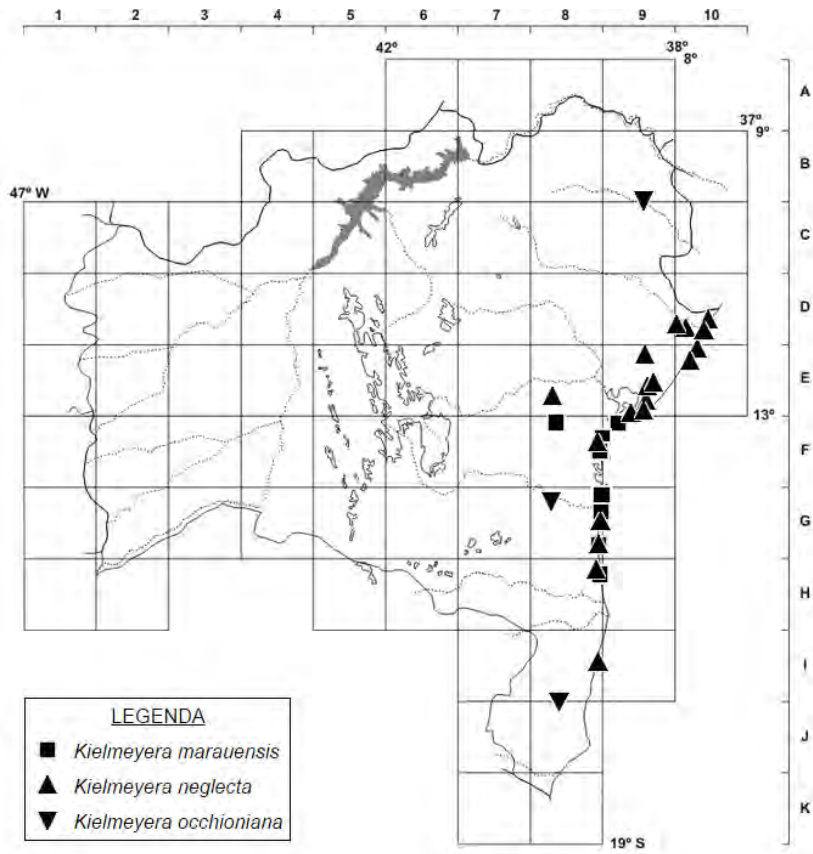

Figura 9. Mapa de distribuição de Kielmeyera marauensis, $K$. neglecta e K. occhioniana no estado da Bahia. compr.; pedicelo 4-10,4 mm compr. Sépalas externas $6-8 \times 7,5-8,2 \mathrm{~mm}$, internas 8-11 $\times$ 8-14 mm, orbiculares a oblatas, base auriculada, ápice redondo a obtuso, margem escariosa, verde-claras, glabras. Pétalas $2-4,2 \times 1,4-2,5 \mathrm{~cm}$, brancas, glabras. Filetes 6-9 mm compr.; anteras ca. 1,5 × $1 \mathrm{~mm}$, subdorsifixas, glândula dorso-apical cupular a oblata, punctada. Ovário ca. $7 \times 3,5 \mathrm{~mm}$, ovado a elíptico; estilete 6-10 mm compr., estigma capitado. Cápsulas ca. $13 \times 4 \mathrm{~cm}$; [sementes não vistas].

Ocorre nos estados de Goiás, Minas Gerais e Bahia, em vegetações de cerrado (Bittrich et al. 2015). C2, E2/3, F2/3, F6: cerrados e campos rupestres. Encontrada principalmente na região da Chapada Diamantina, ocorrendo com menor frequência também no oeste do estado. Floresce entre novembro e abril, podendo estender-se até julho, e frutifica de abril a novembro.

Material selecionado - Abaíra, $13^{\circ} 17^{\prime} 01^{\prime \prime S}, 41^{\circ} 44^{\prime} 37^{\prime \prime} \mathrm{W}$, dez. 2009 (fl.), M.L. Guedes et al. 16568 (ALCB); Andaraí, 13²17'S, 41ํํ'W, dez. 2003 (fl.), E.R. Souza \& A. Oliveira 443 (HUEFS); Barra da Estiva, jul. 1983 (fl.), L. Coradin et al. 6398 (CEN); Barreiras, set. 1996 (fr.), M.A. Mayworm 37 (HUEFS);

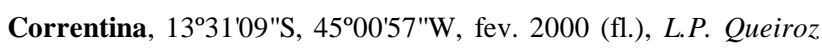
et al. 6072 (ALCB, CEPEC, HRB, HUEFS, HUESC); Formosa do Rio Preto, 10³4'16"S, 45³7'11"W, abr. 2013 (fl.), A. Rapini \& G.B. Siqueira 2014 (HUEFS); Inúbia, 1304'00"S, 41²48'46"W, abr. 2011 (fr.), M.L. Guedes et al. 18883 (ALCB, MBM); Jussiape, 13²6'49"S, 41³2'18"W, jun. 2002 (fr.), L.P. Queiroz et al. 7123

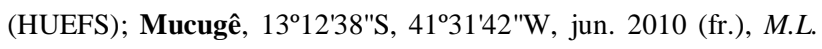
Guedes et al. 17195 (ALCB); Piatã, 1313'43"S, 414ㄴ'57"W, dez. 2003 (fl.), N. Roque et al. 929 (ALCB, HRB); Rio de Contas, $13^{\circ} 34^{\prime} \mathrm{S}, 41^{\circ} 48^{\prime} \mathrm{W}$, jan. 2003 (fl.), F. Guaré s.n. (ALCB 61581); Rio do Pires, $13^{\circ} 15^{\prime} 43^{\prime \prime S}, 41^{\circ} 55^{\prime} 29^{\prime \prime} \mathrm{W}$, abr. 2000 (fl.), F.H.F. Nascimento 351 (HUEFS); São Desidério, 1259'31"S, 45²8'18"W, abr. 2011 (fl.), E.P. Queiroz 4834 (HRB).

Kielmeyera petiolaris é caracterizada pelas sépalas orbiculares a oblatas e lâmina foliar com nervuras secundárias e terciárias pouco visíveis a imperceptíveis e planas a pouco proeminentes adaxialmente, sendo as características das nervuras que a distingue de $K$. bifaria e $K$. lathrophyton, espécies morfologicamente mais próximas. A simpatria com $K$. lathrophyton e a grande variação na morfologia foliar sugerem uma possível hibridação, como registrado por Caddah et al. (2012) para K. coriacea e K. grandiflora (Wawra) Saddi, e dificultam uma delimitação precisa entre essas espécies. Também é semelhante a $K$. bifaria, da qual difere pelos características mencionadas nos comentários daquela espécie.

\subsection{Kielmeyera reticulata Saddi, Bradea 4: 27(28).} 1984.

Figuras 10, 11E, 17I e 18A, B.

Nomes populares: colírio, pau-santo, vaza-matéria.

Arbusto ou árvore, até $6 \mathrm{~m}$ alt., glabro; látex branco-amarelado. Folhas com pecíolo 0,8-2,7 $\mathrm{mm}$ compr., adaxialmente plano; lâmina 4-16 × 2-7,5 cm, 
largamente elíptica a obovada, base cuneada, ápice obtuso a retuso, margem plana ou revoluta, coriácea, levemente discolor; face adaxial marrom-amarelada a verde-amarronzada, com nervura principal imersa (1-2 $\mathrm{mm}$ larg. na base), as secundárias imersas, 2-5 $\mathrm{mm}$ distantes entre si; face abaxial amarelada, com nervura principal proeminente, as secundárias planas a proeminentes; nervuras terciárias pouco visíveis em ambas as faces. Inflorescências em tirsos de cimeiras 1-3-floras; raque 6-11 cm compr.; pedicelo 4-9 $\mathrm{mm}$ compr. Sépalas externas 4-9 × 8-10 mm, internas 9-11 × 3-11 mm, ovadas, base e ápice obtusos, margem escariosa, verdes, glabras. Pétalas 3,6-4 $\times$ 1,1-2,2 cm, brancas, glabras. Filetes 11-14 mm compr.; anteras ca. $3 \times 0,5 \mathrm{~mm}$, subdorsifixas, glândulas ausentes. Ovário ca. $10 \times 6 \mathrm{~mm}$, ovado; estilete 5-8 mm compr., estigma capitado. Cápsulas 8-13,5 × 3-5,5 cm; sementes com núcleo seminífero ca. 1,2 $\times 2 \mathrm{~cm}$ e alas ca. $3 \mathrm{~cm}$ compr.

Endêmica da Bahia, ocorre de forma disjunta em restingas e campos rupestres, onde é pouco frequente. Nas restingas, é eventualmente encontrada em simpatria com $K$. argentea, com a qual pode ser confundida (ver $K$. argentea): D9, E6, E9, E10, F6: encontrada com flores e frutos durante todo o ano.

Material selecionado - Alagoinhas, $12^{\circ} 09^{\prime} 57^{\prime \prime} \mathrm{S}, 38^{\circ} 26^{\prime} 33^{\prime \prime} \mathrm{W}$, fev. 2000 (fl.), F. França et al. 3224 (CEPEC, HUEFS); Aramari,

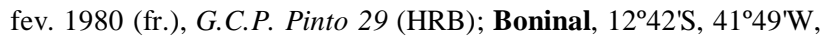
out.1998 (fl.), M.L. Guedes et al. 6642 (ALCB, CEPEC); Camaçari, $12^{\circ} 41^{\prime} \mathrm{S}, 38^{\circ} 19^{\prime} \mathrm{W}$, nov. 2010 (fl.), M.L. Guedes \& F.S. Gomes 17902 (ALCB); Entre Rios, 12 ${ }^{\circ} 15^{\prime} \mathrm{S}, 3^{\circ} 53^{\prime} \mathrm{W}$, jan. 2012 (fl.), A.V. Popovkin 1030 (HUEFS); Esplanada, 1208'67"S, 37050'60"W, maio 2005 (fl., fr.), L. Freire \& M.L. Guedes 95 (ALCB); Inhambupe, fev. 2010 (fl.), J.G. Carvalho-Sobrinho et al. 2726 (HUEFS); Lauro de Freitas, 1251'51"S, 38 $17^{\circ} 02^{\prime \prime} \mathrm{W}$, out. 2006 (fl.), E.P. Queiroz 2114 (HRB); Mata de São João, dez. 2008 (fl., fr.), A.M. Miranda \& J. Ferraz 5861 (ALCB, HST); Mucugê,

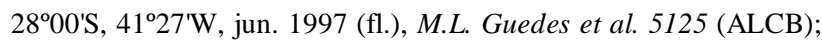

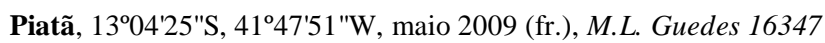

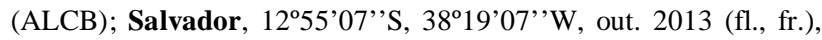
A.P.B. Santos et al. 45 (HUEFS); Santo Antônio de Jesus, $12^{\circ} 27^{\prime} 31^{\prime \prime S}, 37^{\circ} 56^{\prime} 13 " \mathrm{~W}$, nov. 2005 (fl.), P.O. Rebouças 33 (HUEFS); São Sebastião do Passé, abr. 2001 (fl., fr.), M.L. Guedes et al. 8233 (ALCB).

Kielmeyera reticulata caracteriza-se pelo pecíolo plano adaxialmente, folhas com nervuras secundárias imersas adaxialmente e ausência de glândulas na antera. Assemelha-se morfologicamente a K. argentea, da qual pode ser distinguida pelas características apresentadas nos comentários daquela espécie.

3.16. Kielmeyera rubriflora Cambess., Fl. Bras. Merid. (quarto ed.) 1: 305, pl. 60. 1825 [1828].

Figuras 10, 11F, 14M-P e 18C; Saint-Hilaire (1825: tab. 60).

Arbusto, até $3 \mathrm{~m}$ alt.; ramos esparsamente pubescentes a glabrescentes, tricomas dendrítricos; [látex não visto]. Folhas sésseis ou pecioladas; pecíolo
2-7 mm compr., adaxialmente plano, pubescente a tomentoso; lâmina $5-10 \times 1,7-4,5 \mathrm{~cm}$, oblonga a obovada, base cuneada a obtusa, ápice redondo a retuso, margem plana, cartácea a membranácea, discolor; face adaxial verde-amarronzada, glabra, com nervura principal plana (base ca. $1 \mathrm{~mm}$ larg.), as secundárias planas a pouco proeminentes, 1,5-3,5 $\mathrm{mm}$ distantes entre si, as terciárias planas, imperceptíveis; face abaxial verde-clara a verde-pálida, glabra ou com tricomas dendrítricos esparsos ou restritos as nervuras, nervura principal proeminente, as secundárias planas e terciárias planas, densamente reticuladas e visíveis. Inflorescências em tirsos de cimeiras multifloras, contraídas, ou em cimeiras 1-3-floras; raque 2-4 cm compr., tomentosa; pedicelo 7-12 mm compr. Sépalas externas 3-7 × 3-5 mm, internas 4-9 × 3-7 mm, ovadas, base obtusa, ápice agudo a subagudo, margem coriácea, verdes, tomentosas abaxialmente. Pétalas 2,7-4,7 $\times$ 1,5-2,3 cm, róseas, tomentulosas abaxialmente. Filetes 4-6 mm compr.; anteras ca. $2 \times$ $1 \mathrm{~mm}$, dorsifixas, retrorsas, glândulas punctiformes em toda superfície. Ovário ca. $4 \times 3 \mathrm{~mm}$, largamente elíptico, densamente viloso; estilete 5-6 mm compr., lanoso a glabrescente, estigma capitado. [Cápsulas e sementes não vistas].

Bolívia e do Norte ao Sudeste do Brasil, sendo amplamente distribuída no Cerrado (Saddi 1982; Bittrich et al. 2015). C2, E2/3, F2/3, F3, G5: cerrados. Encontrada com flores de novembro a maio e com frutos em abril.

Material selecionado - Barreiras, $12^{\circ} 06^{\prime} 00^{\prime \prime} \mathrm{S}, 44^{\circ} 59^{\prime} 00^{\prime \prime} \mathrm{W}$, maio 1997 (fl.), C. Proença et al. 1753 (MBM, UB); Correntina, mar. 1995 (fl.), G. Hatschbach et al. 61995 (CEPEC, MBM, UEC); Formosa do Rio Preto, 1051'10"S, 4547'23"W, abr. 2013 (fl.), A. Rapini \& G.B. Siqueira 2017 (HUEFS); Licínio de Almeida,

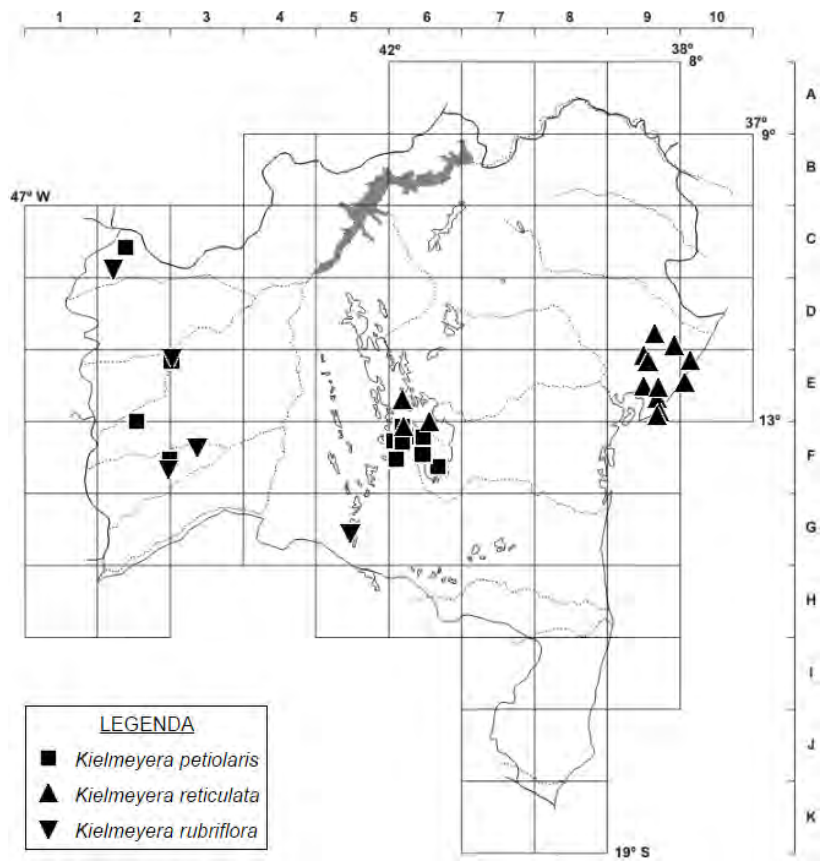

Figura 10. Mapa de distribuição de Kielmeyera petiolaris, K. reticulata e K. rubriflora no estado da Bahia. 

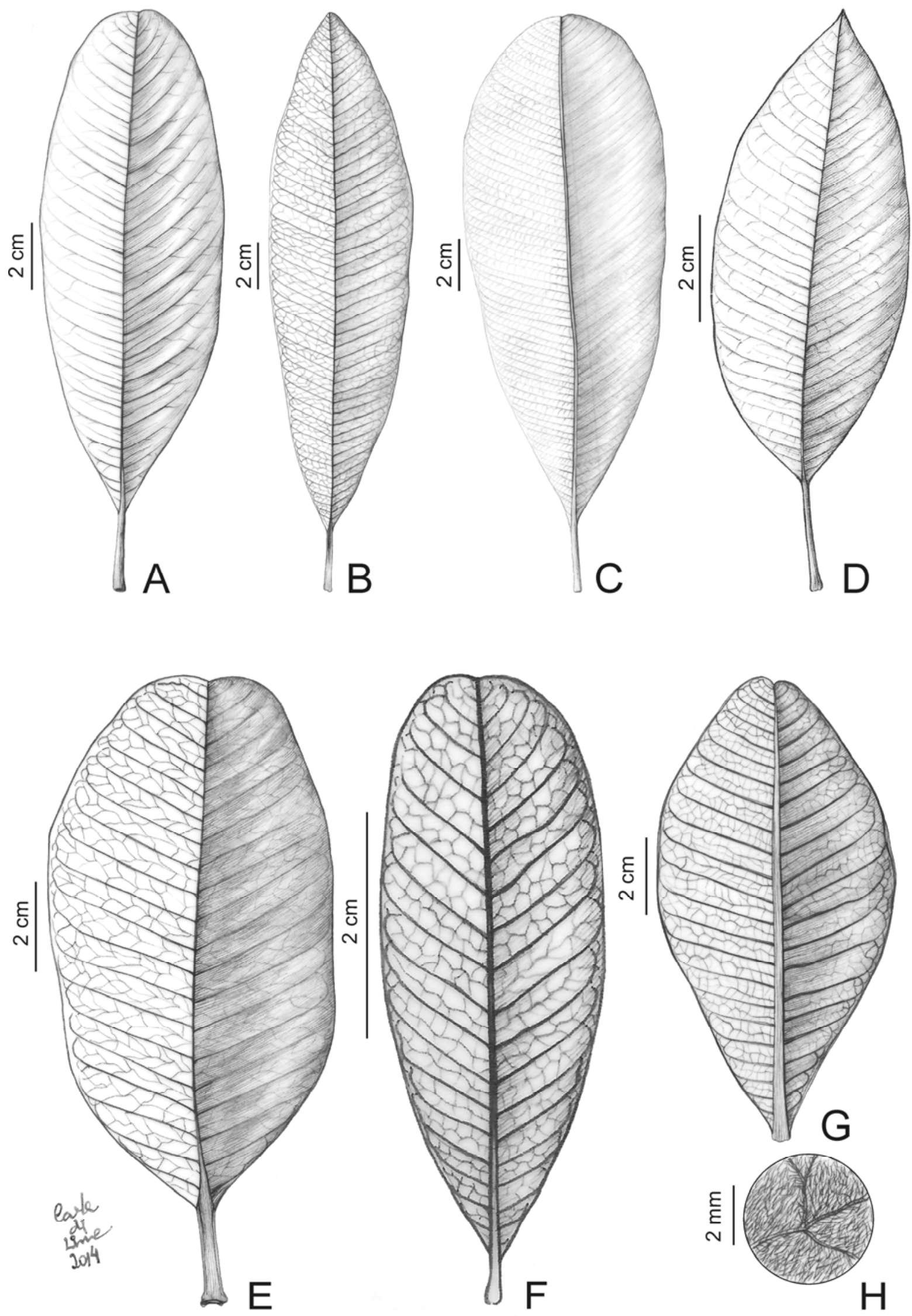

Figura 11. Folhas de Kielmeyera. A. K. marauensis: face adaxial. B. K. neglecta: face abaxial. C. K. occhioniana: face adaxial. D. K. petiolaris: face adaxial. E. K. reticulata: face adaxial. F. K. rubriflora: face abaxial. G, H. K. tomentosa: G- face abaxial; H- detalhe do indumento na face abaxial. (A- Santos 47 HUEFS; B- Santos 49 HUEFS; C- Almeida 31 HUEFS; D- Harley 50179 HUEFS; E- Queiroz 861 HUEFS; F- Souza-Silva 240 HUEFS; G-H- Ganev s.n. HUEFS 26675). 
14²32'15"S, 42³1'51"W, nov. 2006 (fl.), R.F. Souza-Silva et al. 240 (HUEFS, UEC); São Desidério, 133'ㄱ' $33^{\prime \prime S}, 45^{\circ} 01^{\prime} 57^{\prime \prime} \mathrm{W}$, maio 2010 (fl.), E. Melo et al. 8174 (HUEFS).

Kielmeyera rubriflora caracteriza-se pela presença de tricomas dendrítricos nas folhas, sépalas e pétalas, sendo a única espécie no estado com essas características. Entretanto, é muito confundida com $K$. rosea e $K$. regalis, espécies endêmicas de Minas Gerais, e segundo Saddi (1982), difere da primeira pelas sépalas menores e da segunda pelos ramos marrons a avermelhados (vs. acinzentados) e nervuras mais visíveis adaxialmente.

3.17. Kielmeyera rugosa Choisy, Mém. Soc. Phys. Genève 14: 163. 1855.

Figuras 12, 14Q e 18D-G.

Nomes populares: mangue, pau-de-leite.

Arbusto a arvoreta, até $6 \mathrm{~m}$ alt., glabro; látex amarelado. Folhas com pecíolo 0,9-1,5 cm compr., adaxialmente plano; lâmina 4-8,5 × 2,5-4,5 cm, oblongas a elípticas, base cuneada, ápice redondo a retuso, margem plana, cartácea a coriácea, discolor; face adaxial verde-oliva, com nervura principal imersa (ca. $1 \mathrm{~mm}$ larg. na base); face abaxial amarronzada, com nervura principal proeminente; nervuras secundárias planas, pouco visíveis em ambas as faces, ca. $1 \mathrm{~mm}$ distantes entre si; nervuras terciárias planas, imperceptíveis em ambas as faces. Inflorescências em tirsos de cimeiras unifloras; raque ca. $10 \mathrm{~cm}$ compr.; pedicelo 5-8 mm compr. Sépalas internas 4,5-5,5 $\times$ 6,5-7,5 mm, externas 3,5-4,5 × 3,5-5 mm, ovadas, base e ápice obtusos, margem escariosa, verdeamareladas, glabras. Pétalas 2,5-3 $\times 1-1,2 \mathrm{~cm}$, brancas, glabras. Filetes 6-9 mm compr.; anteras ca. 1 $\times 0,6 \mathrm{~mm}$, subdorsifixas, glândula apical rostrada. Ovário ca. $7 \times 4 \mathrm{~mm}$; estilete 5-8, estigma capitado. Cápsulas ca. $9 \times 3 \mathrm{~cm}$; [sementes não vistas].

Ocorre nos estados de Sergipe e Bahia, no domínio da Mata Atlântica (Bittrich et al. 2015). D9, D10: tabuleiros. Floresce de janeiro a maio e pode ser encontrada com frutos em maio.

Material selecionado - Itapicuru, $11^{\circ} 13^{\prime} 43^{\prime \prime} \mathrm{S}, 38^{\circ} 13^{\prime} 08^{\prime \prime} \mathrm{W}$, maio 2014 (fl., fr.), A.P.B. Santos 56 (HUEFS); Rio Real, jan. 1956 (fl.), A. Lima 2515 (IPA, PEUFR, RB).

Kielmeyera rugosa é caracterizada pelo pecíolo adaxialmente plano, nervuras secundárias e terciárias planas em ambas as faces, por possuir sépalas com tamanhos desiguais e glândula das anteras rostrada. É semelhante a $K$. argentea, mas pode ser distinguida desta, pelas características acima citadas (ver, também, os comentários em $K$. argentea).

3.18. Kielmeyera tomentosa Cambess., Fl. Bras. Merid. (quarto ed.) 1: 308; pl. 61. 1825 [1828].

Figuras 11G, H, 12, 14R e 18H, I; Saint-Hilaire (1825: tab. 61).

Nomes populares: pau-santo, tibórnia, unha-de-anta, vaza-matéria.
Árvore, arbusto ou subarbusto, até $8 \mathrm{~m}$ alt.; caule com cortiça; ramos glabros a tomentosos no ápice, tricomas simples; látex amarelado. Folhas sésseis ou pecioladas; pecíolo 0,4-1,2 cm compr., plano adaxialmente; lâmina $6,5-22 \times 2,5-8 \mathrm{~cm}$, elíptica a obovada, base cuneada a atenuada, ápice obtuso a retuso, margem plana, coriácea, discolor; face adaxial verde-amarronzada, escrobiculada, glabra, raramente tomentosa, com nervura principal plana $(2-4,5 \mathrm{~mm}$ larg. na base), as secundárias planas, 2,5-6,5 mm distantes entre si, as terciárias imperceptíveis; face abaxial verde-pálida a marrom, tomentosa, tomentulosa ou esparsamente hirsuta, com nervura principal proeminente, as secundárias proeminentes, as terciárias frequentemente proeminentes. Inflorescências em tirsos de cimeiras 1-3-floras; raque 8-15 cm compr., glabra, tomentosa a tomentulosa ou hirsuta; pedicelo 7-19 mm compr., tomentoso ou tomentuloso. Sépalas internas 6-8,5 × 4-6 mm, as externas 5-8 × 3,5-4 mm, ovadas, base obtusa, ápice subagudo, margem coriácea e ciliada, verdes, tomentosas. Pétalas 2,5-3 × 1,2-1,9 $\mathrm{cm}$, brancas a róseas, margem coriácea, ciliada, tomentosas abaxialmente. Filetes 6-9 mm compr.; anteras ca. $3 \times 0,8 \mathrm{~mm}$, subdorsifixas, glândula dorsoapical globosa. Ovário ca. $7 \times 4 \mathrm{~mm}$, elíptico a largamente elíptico, glabro; estilete 7,5-8,5 $\mathrm{mm}$ compr., estigma clavado. Cápsulas (imaturas) 9-11× 3-4 cm; [sementes não vistas].

Endêmica do Brasil, ocorrendo no Cerrado do Distrito Federal, Goiás, Mato Grosso, Minas Gerais e Bahia (Bittrich et al. 2015). E6, E/F9, F2/3, F6, G3, G4, G5: cerrados e campos rupestres; raramente encontrada disjunta em restingas. Floresce de novembro a junho e pode ser encontrada com frutos durante o ano todo.

Material selecionado - Abaíra, $13^{\circ} 17^{\prime} 05^{\prime \prime} \mathrm{S}, 41^{\circ} 53^{\prime} 16^{\prime \prime W}$, dez. 2009 (fl.), M.L. Guedes et al. 16569 (ALCB); Caetité, dez. 2009 (fl.), L.J. Alves et al. 115 (HUEFS); Carinhanha, 14 $4^{\circ} 13^{\prime} \mathrm{S}, 43^{\circ} 52^{\prime} \mathrm{W}$, set. 1996 (fr.), G.P. Silva et al. 3690 (CEN, UEC); Cocos, $14^{\circ} 17^{\prime} 18^{\prime \prime} \mathrm{S}, 44^{\circ} 43^{\prime} 02^{\prime \prime W}$, maio 2001 (fr.), F. França et al. 3620

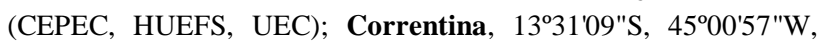
fev. 2000 (fr.), L.P. Queiroz et al. 6107 (ALCB, CEPEC, HUEFS); Feira da Mata, $14^{\circ} 13^{\prime} 54^{\prime \prime} \mathrm{S}, 4^{\circ} 12^{\prime} 45^{\prime \prime} \mathrm{W}$, maio 2007 (fr.), M.L. Guedes et al. 13403 (ALCB, HUEFS); Ibicoara, 1317'25"S, 4131'54"W, dez. 2009 (fl.), M.L. Guedes et al. 16570 (ALCB); Inúbia, $13^{\circ} 04^{\prime} \mathrm{S}, 41^{\circ} 48^{\prime} \mathrm{W}$, abr. 2011 (fr.), M.L. Guedes et al. 18879 (ALCB); Itaetê, $13^{\circ} 09^{\prime} \mathrm{S}, 41^{\circ} 06^{\prime} \mathrm{W}$, abr. 2001 (st.), D.M. Loureiro et

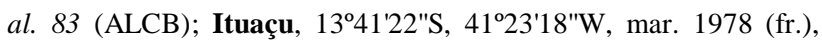
A.P. Araújo 51 (HRB, RB); Lençóis, $12^{\circ} 28^{\prime} 00^{\prime \prime} \mathrm{S}, 41^{\circ} 24^{\prime} 48^{\prime \prime} \mathrm{W}$, jan. 2010 (st.), R.J. Trad et al. 67 (UEC); Mucugê, 1304'20"S, 41 29 '54"W, jun. 2007 (fl.), M.L. Guedes et al. 17145 (ALCB); Palmeiras, $12^{\circ} 27^{\prime} 00 " \mathrm{~S}, 41^{\circ} 28^{\prime} 00^{\prime \prime} \mathrm{W}$, dez. 2012 (fl.), L.S. Funch et

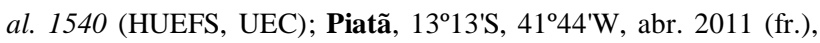
M.L. Guedes et al. 18895 (ALCB, MBM); Rio de Contas, $13^{\circ} 31^{\prime} \mathrm{S}$, 41 53 'W, abr. 2011 (fr.), M.L. Guedes et al. 18871 (ALCB, MBM); Salvador, $12^{\circ} 58^{\prime} \mathrm{S}, 38^{\circ} 30^{\prime} \mathrm{W}$, nov. 2012 (fl.), M.L. Guedes et al.

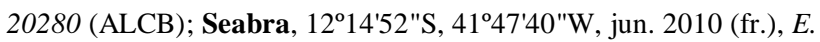
Melo et al. 8356 (HUEFS). 
Kielmeyera tomentosa caracteriza-se pelas folhas com tricomas e nervuras secundárias proeminentes na face abaxial, o que a diferencia de $K$. coriacea, espécie mais próxima morfologicamente. Saddi (1982) considerou $K$. tomentosa como subespécie de $K$. coriacea, entretanto, com base nas características morfológicas supracitadas e em diferenças anatômicas encontradas por Trad (2012) reconhecemos este táxon como uma espécie distinta.

\section{Mammea L.}

Árvores; ramos glabros. Folhas opostas, decussadas, lâmina coriácea; venação reticulada. Inflorescências com flores solitárias ou fasciculadas, axilares. Flores mono ou diclinas. Sépalas 2 ou 3, elípticas a ovadas, coriáceas. Pétalas $4-6$ ou 8 , elípticas, brancas. Estames numerosos, conados na base; anteras com ou sem glândulas. Ovário 2-4carpelar, 2-4(-8)-locular, 1 ou 2 óvulos por lóculo; estigma peltado, 2(-4)-lobado. Baga globosa a elíptica. Sementes 2-4(8), oblongas a arqueadas, sem alas.

Mammea possui cerca de 80 espécies, principalmente na Ásia tropical e Madagascar, além da África tropical, Australásia e América Central (Xi Wen et al. 2007). Na América do Sul, ocorre apenas $M$. americana, amplamente cultivada para consumo de seus frutos e por seu potencial ornamental (Francis 1989).

\subsection{Mammea americana L., Sp. Pl. 1: 512. 1753.}

Figuras 12 e 13H-K; Engler (1888: tab. 79).

Árvore, até $9 \mathrm{~m}$ alt., glabra; látex amarelo. Folhas com pecíolo 1,5-2,2 cm compr., canaliculado; lâmina 16-20 × 8,5-11 cm, elíptica, base redonda a cuneada, ápice obtuso a subagudo, margem plana, coriácea, discolor; face adaxial verde-escura, com nervura principal imersa; face abaxial verde-amarelada, com nervura principal proeminente; nervuras secundárias e terciárias discretamente proeminentes em ambas as faces. Flores solitárias; pedicelo 17-22 mm compr. Sépalas 2, 1,4-1,5 $\times 1,0-1,2 \mathrm{~cm}$, ovadas a elípticas, ápice e base obtusos, côncavas, reflexas, coriáceas, verdes, glabras. Pétalas 4 , $1,2-1,4 \times 0,7-0,9 \mathrm{~cm}$, reflexas, brancas, glabras. Filetes 4-6 mm compr.; anteras ca. $2 \times 0,6 \mathrm{~mm}$, basifixa, glândula apical rostrada. Ovário ca. $8 \times 7 \mathrm{~mm}$, globoso; estilete ca. $5 \mathrm{~mm}$ compr., estigma peltado, bilobado. Bagas (imaturas) ca. 5,5 $\times 4,5 \mathrm{~cm}$, globosas, verdes a marrom-claras; [sementes não vistas].

Mammea americana é uma espécie naturalizada no Brasil, ocorrendo em áreas antropizadas nos estados do Amazonas, Pará, Bahia e Rio de Janeiro (Engler 1888; Bittrich et al. 2015). Na Bahia, foi encontrada apenas cultivada na área do Centro de Pesquisas do Cacau (CEPEC). Coletada com flores e frutos em abril e agosto.

Material examinado - Ilhéus, ago. 1981 (fl., fr.), J.L. Hage 1153 (CEPEC); ib., abr. 1984 (fl., fr.), T.S. Santos 3924 (ALCB, CEPEC).

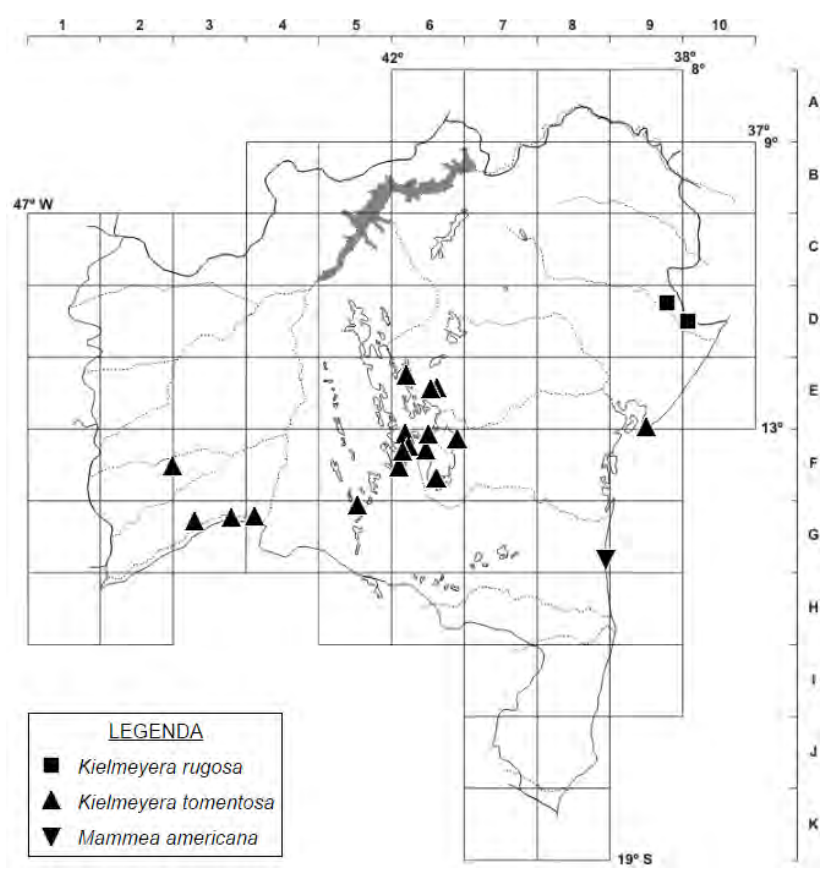

Figura 12. Mapa de distribuição de Kielmeyera rugosa, K. tomentosa e Mammea americana no estado da Bahia.

Mammea americana é distinta das demais espécies da Bahia por suas folhas opostas com venação reticulada, pelas inflorescências fasciculadas ou flores solitárias e pelos frutos tipo baga.

\section{Agradecimentos}

Agradecemos à Coordenação de Aperfeiçoamento de Pessoal de Nível Superior (Capes), pela bolsa de mestrado concedida à primeira autora, e ao Conselho Nacional de Desenvolvimento Científico e Tecnológico (CNPq), pelas bolsas de doutorado e de produtividade (Pq1D) concedidas ao segundo e terceiro autores, respectivamente. Os trabalhos de campo e visitas a herbários foram subsidiados pelos projetos Flora da Bahia, PROTAX e Universal (485468/2013-1), financiados pelo CNPq. Finalmente, agradecemos à Fundação de Amparo à Pesquisa do Estado da Bahia (FAPESB) pelo ao auxílio dissertação (005/2014).

\section{REFERÊNCIAS}

Bittrich, V. \& Rodrigues, W.A. 2009. Clusiaceae. In: A.M. Giulietti, A. Rapini, M.J.G. Andrade, L.P. Queiroz \& J.M.C. Silva (orgs), Plantas Raras do Brasil. Conservação Internacional, Belo Horizonte, p. 139-141.

Bittrich, V.; Trad, R.J.; Cabral, F. \& Nascimento-Jr, J.E. 2015. Calophyllaceae. In: Lista de Espécies da Flora do Brasil. Jardim Botânico do Rio de Janeiro. Disponível em http://floradobrasil.jbrj.gov.br/jabot/floradobrasil/FB6855; acesso em 28 jan. 2015. 


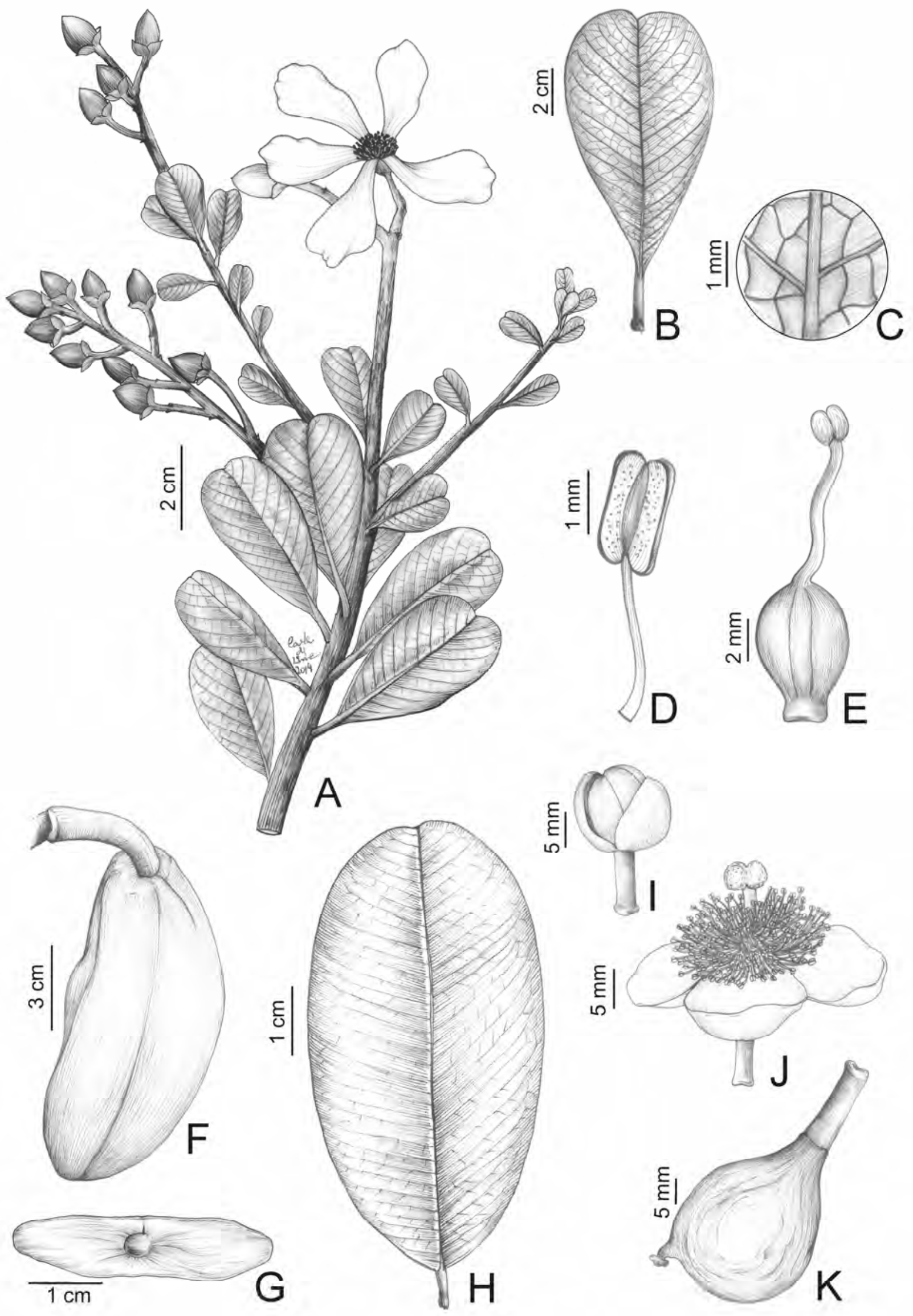

Figura 13. A-G. Kielmeyera argentea: A- ramo com flor e botões; B- folha (face adaxial); C- detalhe das nervuras (face adaxial); D- estame; E- gineceu; F- fruto; G- semente. H-K. Mammea americana: H- folha (face adaxial); I- botão floral; J- flor; K- fruto imaturo. (A-C- Viana 7 HUEFS; D, E- Souza 3 HUEFS; F- Silva 171 HUEFS; G- Santos 44 HUEFS; H-K- Santos 3924 CEPEC). 


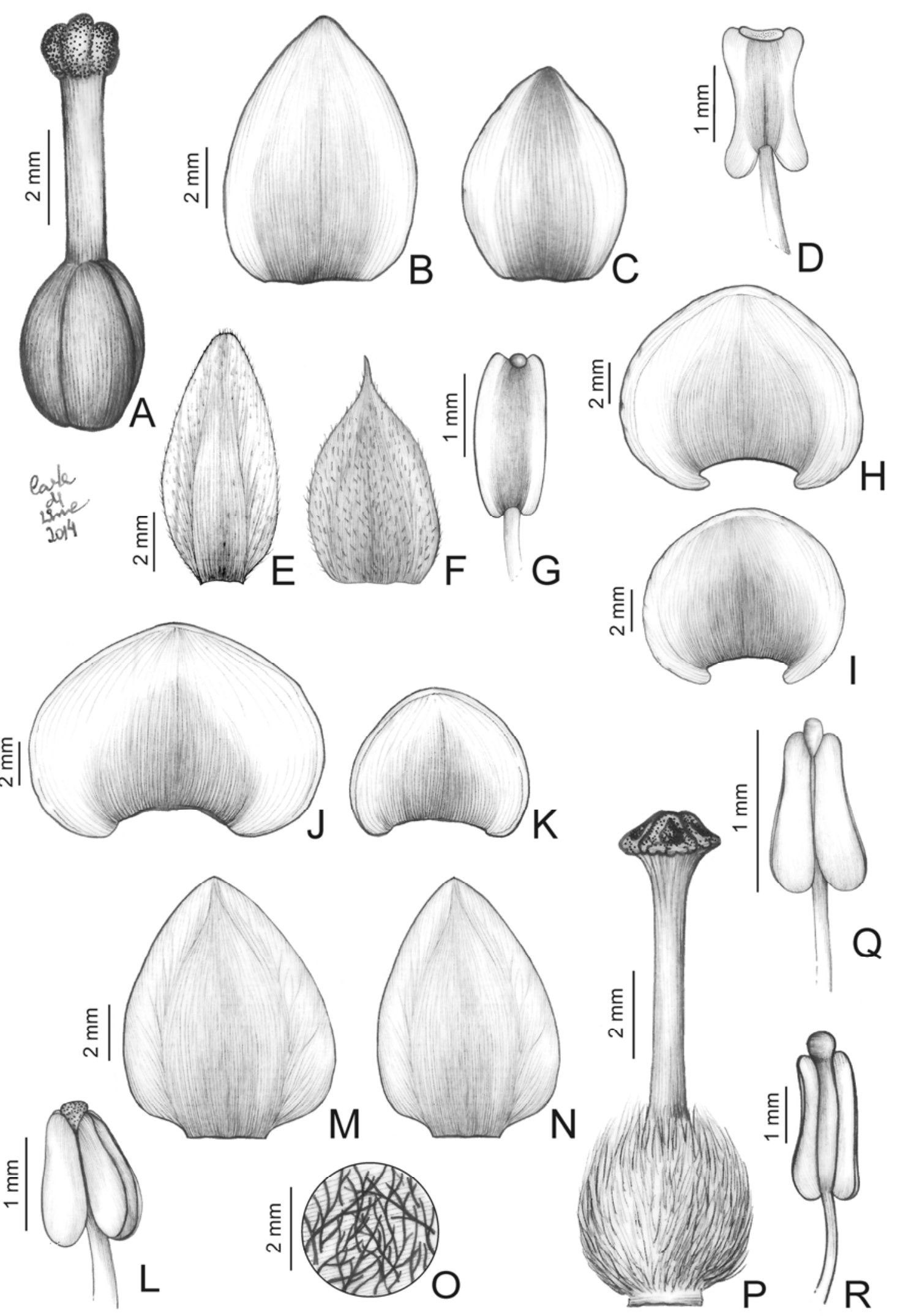

Figura 14. Caracteres florais de Kielmeyera. A. K. abdita: gineceu. B, C. K. albopunctata: B- sépala interna; C- sépala externa. D. $K$. bifaria: parte do estame. E, F. $K$. cuspidata: E- sépala interna; F- sépala externa. G. K. elata: parte do estame. H, I. K. lathrophyton: H- sépala interna; I- sépala externa. J, K. K. marauensis: J- sépala interna; K- sépala externa. L. K. petiolaris: parte do estame. M-P. K. rubriflora: M- sépala interna; N- sépala externa; O- detalhe do indumento das sépalas; P- gineceu. Q. K. rugosa: parte do estame. R. K. tomentosa: parte do estame. (A- Conceição 4206 HUEFS; B, C- Aona 2160 HUEFS; D- Nascimento 334 HUEFS; E, FFrança 4134 HUEFS; G- Harley 17138 HUEFS; H, I- Funch 618 HUEFS; J, K- Santos 47 HUEFS; L- Queiroz 6072 HUEFS; M-OYoshida-Arns 620 HUEFS; P- Souza-Silva 240 HUEFS; Q- Santos 56 HUEFS; R- Ganev 2612 HUEFS). 

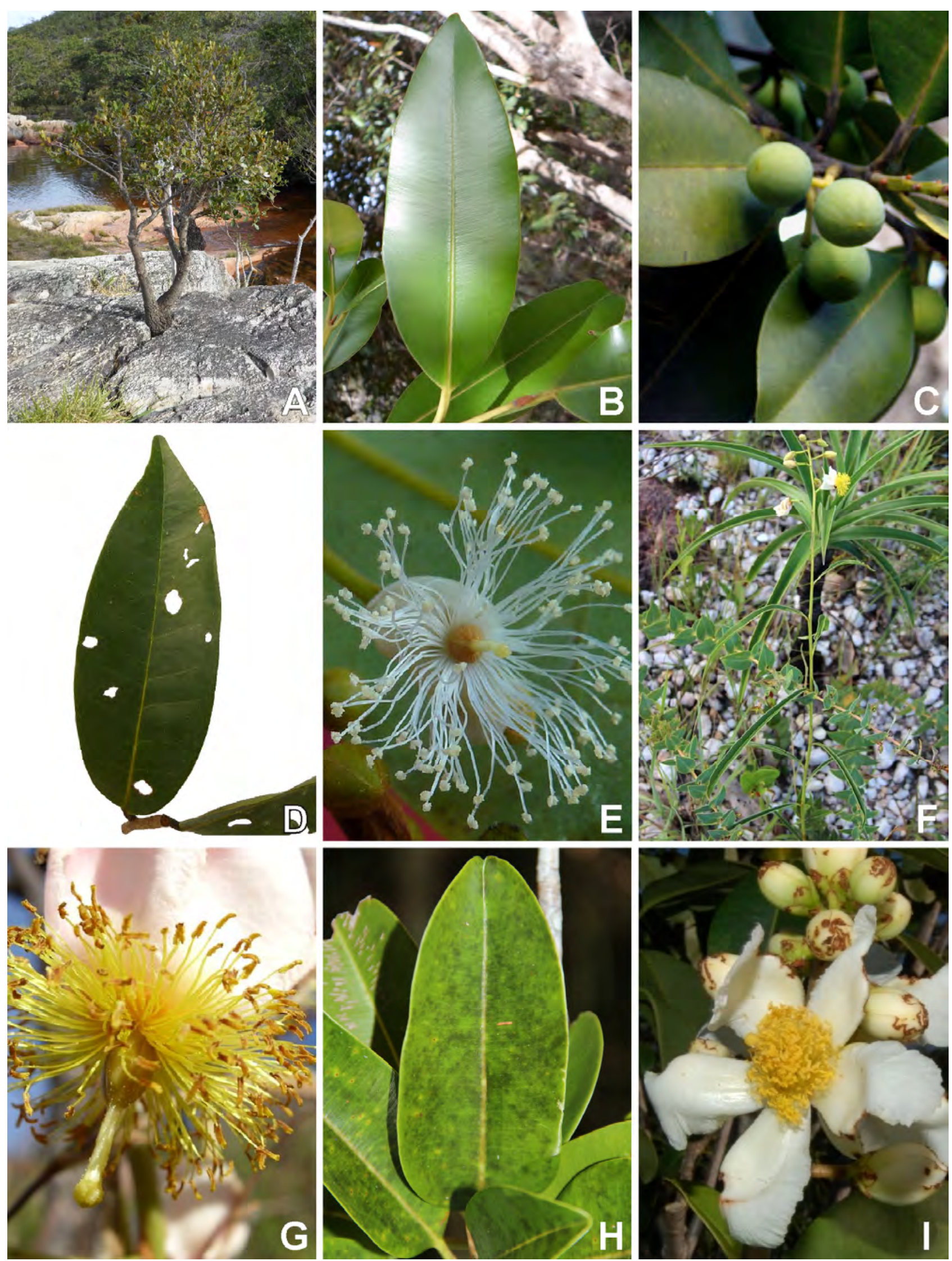

Figura 15. A-C. Callophyllum brasiliense: A- hábito; B- folha (face adaxial); C- frutos. D, E. Caraipa densifolia: D- folha (face adaxial); E- flor. F, G. Kielmeyera abdita: F- hábito; G- flor. H, I. K. albopunctata: H- folha (face adaxial); I- flor. (Fotos: A-C, H- Amanda P.B. Santos; D, E- Alex Popovkin; F- Alessandra Fidelis; G- Ivan Abreu; I- Lidyanne Y.S. Aona). 


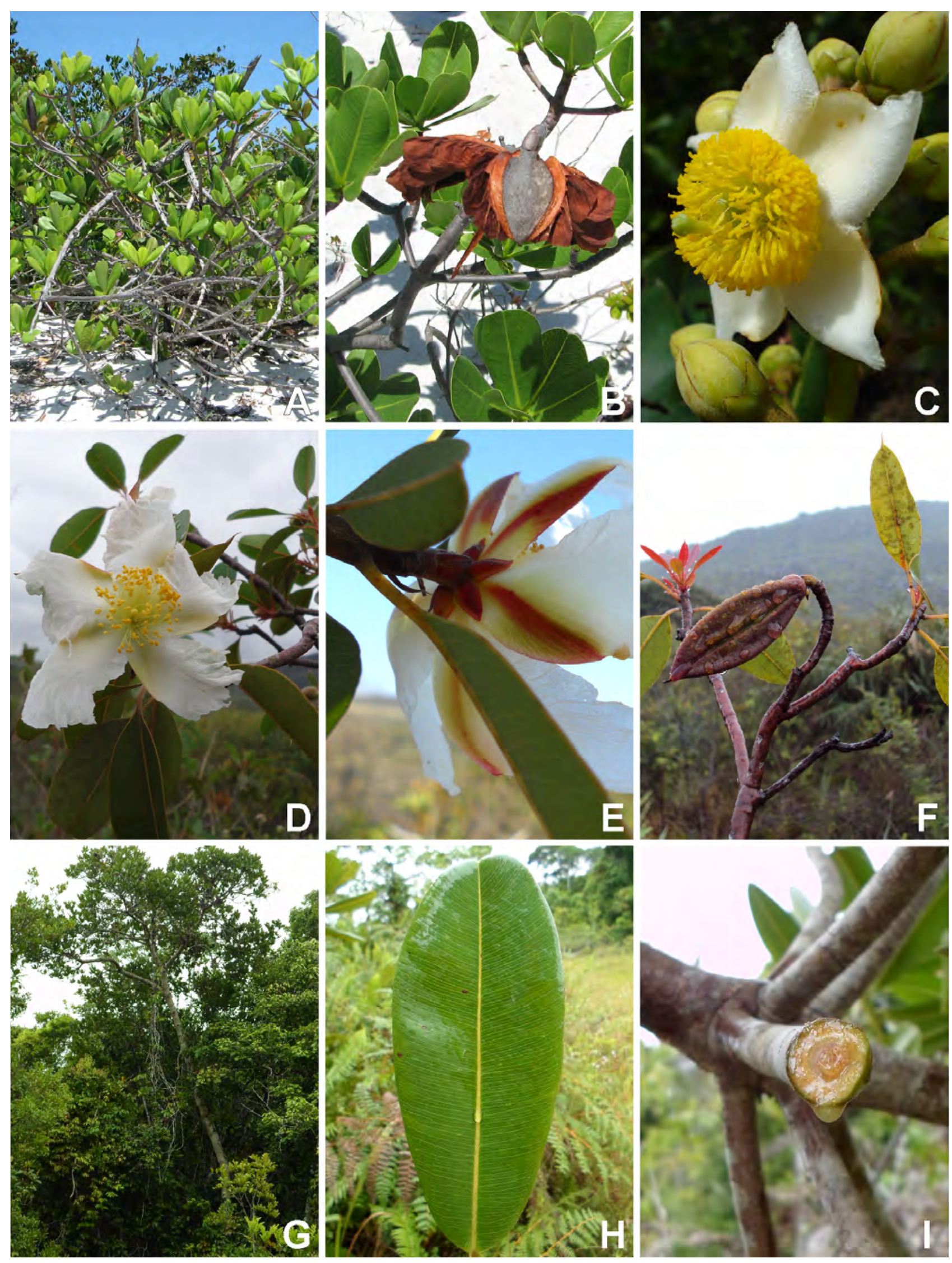

Figura 16. A, B. $K$. argentea: A- hábito; B- fruto. C. Kielmeyera coriacea: flor. D-F. $K$. cuspidata: D- flor; E- face abaxial da flor (sépalas); F- fruto. G-I. K. elata: G- hábito; H- folha (face adaxial); I- ramo cortado, mostrando o látex. (Fotos: A, B, G-I- Amanda P.B. Santos; C- Climbiê F. Hall; D, F- Carla T.V.D. Martins; E- Karena Pimenta). 

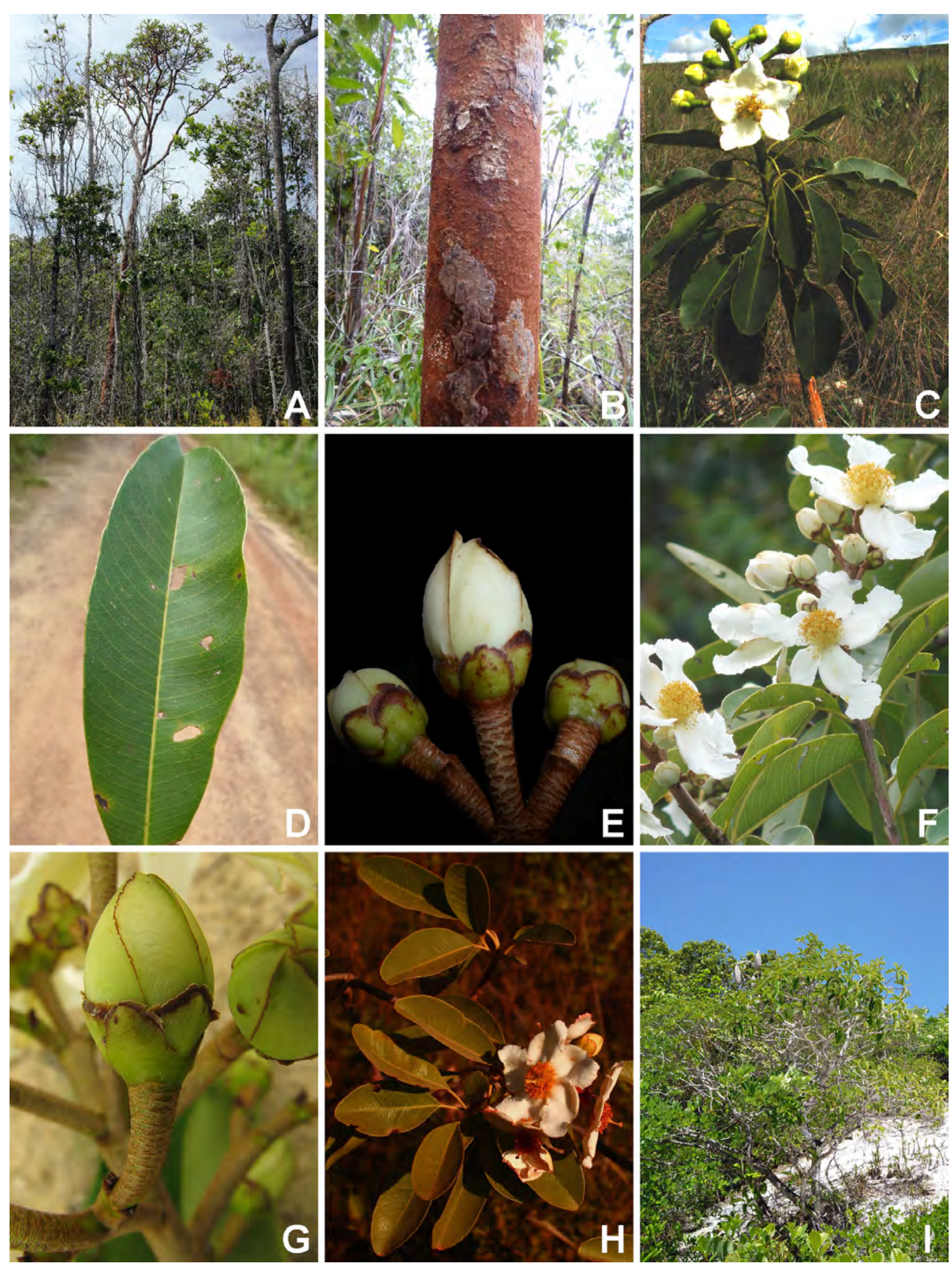

Figura 17. A, B. K. ferruginosa: A- hábito; B- tronco. C. K. lathrophyton: hábito. D-F. Kielmeyera marauensis: D- folha (face adaxial); E- botões florais; F- inflorescência. G. K. neglecta: botão floral. H. K. petiolaris: folhas e inflorescência. I. K. reticulata: hábito. (Fotos: A, B, D, E- Amanda P.B. Santos; C, H- Alessandro Rapini; F- Denis Nunes; G- Alex Popovkin; I- Fabio Espírito Santo). 

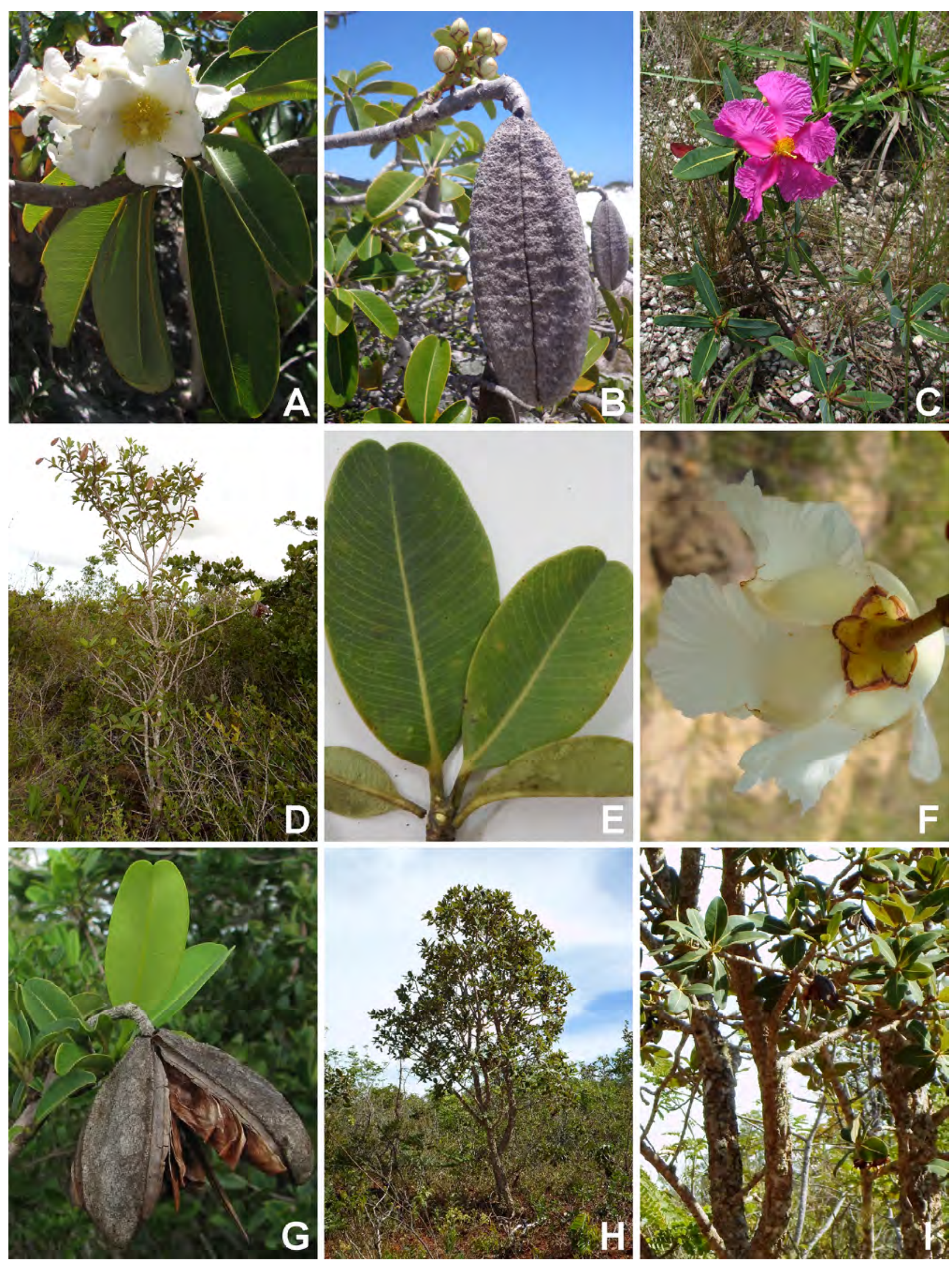

Figura 18. A, B. K. reticulata: A- folhas e inflorescência; B- fruto. C. K. rubriflora: hábito com flor. D-G. Kielmeyera rugosa: D- hábito com frutos; E- folhas (faces adaxial e abaxial); F- face abaxial da flor (sépalas); G- fruto. H, I. K. tomentosa: H- hábito; I- ramos e folhas. (Fotos: A, D-I- Amanda P.B. Santos; B- Ivan Abreu; C- Alessandro Rapini). 
Caddah, M.K.; Mayer, J.L.S.; Bittrich, V. \& Amaral, M.C.E. 2012. Species limits in the Kielmeyera coriacea complex (Calophyllaceae) - a multidisciplinary approach. Botanical Journal of the Linnean Society 168: 101-115.

Coelho, M.A.N.; Valente, A.S.M.; Maurenza, D.; Fernandez, E.P. \& Penedo, T.S.A. 2013. Clusiaceae. In G. Martinelli \& M.A. Moraes (orgs), Livro Vermelho da Flora do Brasil. Andrea Jakobsson Estúdio, Rio de Janeiro, p. 448-450.

D'Arcy, W.G. 1987. Flora de Panama. Checklist and index. Part I: The introduction and checklist. Missouri Botanical Garden Press, Saint Louis.

Díaz, D.M.V. 2013. Multivariate analysis of morphological and anatomical characters of Calophyllum (Calophyllaceae) in South America. Botanical Journal of the Linnean Society 171: 587-626.

Engler, A. 1888. Guttiferae et Quiinaceae. In: C.F.P. Martius, A.G. Eichler \& I. Urban (eds) Flora Brasiliensis. Vol. 12, part. I, fasc. 102. Frid. Fleischer, Monachii, p. 381-486; tab. 62-77.

Ewan, J. 1951. Taxonomic notes on various species of Musaceae, Marcgraviaceae, Guttiferae, and Solanaceae of Colombia. Natural History Miscellanea 88: 1-9.

Francis, J.K. 1989. Mammea americana L. Mamey, mammeeapple. Department of Agriculture, Forest Service, New Orleans. Disponível em: http://www.fs.fed.us/global/iitf/Mammeaameric ana.pdf; acesso em 14 fev. 2015.

Gustafsson, M.H.G.; Bittrich, V. \& Stevens, P.F. 2002 Phylogeny of Clusiaceae based on $r b c L$ sequences. International Journal of Plant Sciences 163(6): 1045-1054.

Kubitzki, K. 1978. Caraipa. The botany of the Guayana highland Part X. Memoirs of the New York Botanical Garden 29: 82-131.

Martius, C.F.P. 1824. Ternstroemiaceae. In: Nova Genera et Species Plantarum Brasiliensium. Vol. 1. Typis Lindaueri, Monachii, p. 103-121.

Saddi, N. 1982. A Taxonomic Revision of the Genus Kielmeyera Martius (Guttiferae). Tese de Doutorado. University of Reading.

Saddi, N. 1984. Some new taxa in Kielmeyera (Guttiferae). Kew Bulletin 39(4): 729-740.
Saddi, N. 1987. New species of Kielmeyera (Guttiferae) from Brazil. Kew Bulletin 42(1): 221-230.

Saint-Hilaire, A.F.C.P. 1825. Ternstroemiaceae. In: Flora Brasiliae Meridionalis. Vol. 1. A. Belin, Paris, p. 296-310.

Souza, V.C. \& Lorenzi, H. 2012. Botânica Sistemática: guia ilustrado para identificação das famílias de angiospermas da flora brasileira, baseado em APGIII. 3 ed. Instituto Plantarum, Nova Odessa.

Stevens, P.F. 2007. Clusiaceae-Guttiferae. In: K. Kubitzki (ed.), The Families and Genera of Vascular Plants. Springer, Berlin, p. $48-66$.

Stevens, P.F. 2001 em diante. Calophyllaceae. Angiosperm Phylogeny Website. Version 13, September 2013 [and more or less continuously updated since]. Disponível em http://www.mobot.org/MOBOT/research/APweb/; acesso em 5 jan. 2015.

Trad, R.J. 2012. Estudos Taxonômicos e Biossistemáticos no Complexo Kielmeyera coriacea Mart. \& Zucc. (Caloplyllaceae). Dissertação de Mestrado em Biologia Vegetal, Universidade Estadual de Campinas.

Wawra, H. 1886. Ternstroemiaceae. In: C.F.P. Martius, A.G. Eichler \& I. Urban. Flora Brasiliensis. Vol. 12. part. I, fasc. 97. Frid. Fleischer, Monachii, p. 258-334.

Woodson, R.E.; Schery, R.W. \& D'Arcy, W.G. 1980. Flora of Panama. Guttiferae. Part IV. Annals of the Missouri Botanical Garden 67: 969-1043.

Xi Wen, L.; Jie, L.; Robson, N.K.B. \& Stevens, P.F. 2007. Clusiaceae. In: Flora da China. Vol. 13. Disponível em http://www.efloras.org/volume_page.aspx?volume_id=2013\&fl ora_id=2; acesso em 13 jan. 2015.

Xi, Z.; Ruhfel, B.R.; Schaefer, H.; Amorim, A.M.; Sugumaran, M.; Wurdack, K.J.; Endress, P.K.; Matthews, M.L.; Stevens, P.F.; Matthews, S. \& Davis, C.C. 2012 Phylogenomics and a posteriori data partitioning resolve the Cretaceous angiosperm radiation Malpighiales. Proceedings of the National Academy of Sciences 109(43): 17519-17524.

\section{LISTA DE EXSICATAS}

Agobar, M. 19 (1.1); Almeida, V.S. 31 (3.13); Almeida-Silva, G. 141 (3.10); Alves, L.J. 62 (3.7), 101 (1.1), 115 (3.18), 238 (3.10); Alves, M. s.n. IPA 56441, PEUFR 25273, UFP 20099 (1.1), s.n. IPA 56369, PEUFR 23750 (3.10), s.n. HRB 37810, IPA 60703, PEUFR 25318, UFP 19532 (3.15); Amorim, A.M.A. 1343 (3.12), 1879 (2.1), 2756 (3.2), 3873 (3.1), 6767 (1.1), 6900 (3.13), 7685 (3.2); Anderson, W.R. 36430 (3.5), 36509 (3.16), 36819 (3.5); Andrade-Lima, D. 2515 (3.17); Anjos, B.A. 60 (3.5); Aona, L.Y.S. 2160 (3.2); Araújo, A.P. 51 (3.18), 214 (3.12); Araújo, J.S. 63 (3.3); Arbo, M.M. 7552 (3.6); Athayde, P. s.n. RB 109038 (3.3); Atkins, S. s.n. ALCB 35973, HRB 37260, HUEFS 29155 (1.1), s.n. ALCB 35986, CEPEC 79619 (3.6); Azevedo, M.L.M. 1314 (3.5), 1337 (3.10); Bastos, A. HUEFS 42993 (3.15); Batista, L.P. 14 (3.6); Bautista, H.P. 1357 (3.15), 1522 (1.1), 1572 (3.3), 1712 (3.12), 1751 (2.1), s.n. HRB 30466, HRB 37460, HUEFS 25922 (3.6), s.n. HRB 36359, HUESC 8231, IBGE 58193 (3.10), s.n. ALCB 33135, CEPEC 76393, HUEFS 62129 (3.18); Belém, R.P. 1044, 1047 (3.7), 2043 (3.11), 2788, 2794 (2.1), 3235 (3.7), 3282 (1.1), 3464 (3.11); Bergossi, A.M. 3 (3.15); Blanchet, J.S. 1671 (3.15), 1904 (3.3), 3268 (3.17); Borges, R.A.X. 726 (3.11); Brandão, J.E.M. 27 (3.18); Brazão, J.E. 203 (3.4); Bridgewater, S. 1013 (3.5); Cabral, V. s.n. BAH 1838 (3.3); Callejas, R. 1715 (2.1); Campos, M. s.n. ALCB 21768 (3.15); Cano, O. 946 (3.1); Cardoso, D. 1664 (3.11); Carneiro-Torres, D.S. 582 (3.1); Carvalhal, I. s.n. ALCB 19301, ALCB 21349 (3.15); Carvalho, A.M. 697, 712 (3.15), 716 (3.3), 1035 (3.10), 1064 (1.1), 1821, 1824 (3.18), 1907 (3.15), 2509 (1.1), 3323 (3.3), 3327 (3.15), 4011 (3.14), 4415 (3.12), 7052 (3.6), s.n. CEPEC 68577, HRB 33715, UEC 104580 (1.1); Carvalho, P.D. 306 (1.1); Carvalho-Sobrinho, J.G. 256 (3.12), 312 (3.10), 724 (3.5), 2726 (3.15); Cavalcante, T. 4 (3.5); Cerati, T.M. 321 (3.6); Coimbra, C.S. s.n. ALCB 23296 (3.15); Collares, J.E.R. 108 (3.5), 136 (3.16); Conceição, A.A. 1667 (3.18), 1876 (3.6), 2471 , 2634 (1.1), 4206 (3.1); Coradin, L. 6398 (3.14); Correia, C. 2 (3.15), 502 (3.2); Costa, A.L. 848, 985, s.n. ALCB 2776 (3.3), s.n. ALCB 15409, s.n. ALCB 2783 (3.15); Costa, C.B. 315 (3.3); Costa, J. 47 (3.3), 273 (3.15); Cotias, A.L. s.n. ALCB 50479 (3.15); Cotrim, A. 305 (3.5); Daneu, L. 408 (1.1); Daniel s.n. ALCB 65923 (3.3); Dias, B.J. 10, 102 (3.5), 125 (3.10); Duarte, A.P. 6641 (3.7), 14172 (3.15), s.n. RB 176569 (3.3); Eupunino, A. 174 (3.2), 249 (3.12); Faria, L.S.S. 50 (3.15); 
Felitto, G. 678 (3.5); Fernandez, M.M. 3 (3.10); Ferreira, J.D.C.A. 343 (3.6); Ferreira, M.C. 652 (2.1), 853 (3.12), 1158 (3.6), 1297 (3.2); Ferreira, V.S. 84 (3.6); Fiaschi, P. 2541 (1.1); Fonseca, M.L. 2882, 3035, 5602 (3.10); Fonseca, M.R. 72 (3.15), 1084, 1094 (1.1), 1100 (2.1), s.n. ALCB 51881 (3.12); França, F. 1016 (3.2), 1182 (3.15), 2115 (3.12), 2643 (1.1), 3224 (3.15), 3620 (3.18), 3728 (1.1), 3966 (3.18), 4134 (3.6); Freire, L. 95 (3.15); Funch, L.S. 93, 178, 184, 203, 732, 826 (1.1), 1540 (3.18); Funch, R. 447 (3.6), 569,618 (3.10), 757 (3.6); Ganev, W. 346 (3.18), 1504 (3.14), 1521 (3.18), 1630 (3.1), 1658 (3.6), 1703 (3.10), 1779 (3.1), 2364,2491 (1.1), 2593 (3.14), 2612, 2656 (3.18), 2834 (3.6), s.n. HUEFS 26675 (3.18); Giulietti, A.M. s.n. UFP 4213 (3.6); Gomes, F.S. 582 (3.6), 688 (3.12), 957 (3.6); Gottsberger, G. 19 (3.16); Guaré, F. s.n. ALCB 61581, ALCB 61582 (3.4), s.n. ALCB 75134, ALCB 75126 (3.5), s.n ALCB 74920, HRB 54321 (3.15); Guedes, M.L. 194 (3.12), 222 (3.3), 646 (1.1), 963 (3.15), 1035 (3.3), 1235 (1.1), 3247 (3.12), 3341 (3.15), 3570 (1.1), 3643 (2.1), 4964 (3.6), 5106, 5113 (3.18), 5125 (3.15), 5143, 5228a (3.6), 5453, 5454 (3.18), 5460 (3.18), 6015 (3.15), 6201,6207 (3.5), 6353 (3.11), 6355 (2.1), 6642 (3.15), 6843 (3.12), 7658 (3.18), 7708 (2.1), 8118, 8233, 8305, 8306 (3.15), 9220 (1.1), 9918 (3.6), 10076 (3.6), 10100 (3.3), 10125 (1.1), 10270 (3.10), 10340, 10386 (3.18), 10648 (1.1), 10942 (3.10), 11277, 11384 (3.18), 11471 (3.2), 12557 (3.18), 13311 (3.6), 13403 (3.18), 13421, 13422, 13482 (1.1), 13705 (3.10), 14310, 14560, 14561, 14562, 14563 (3.18), 14592 (3.5), 14592a (3.6), 14595 (3.10), 14668 (1.1), 14782, 15136 (3.1), 16347 (3.15), 16481 (3.13), 16564 (3.18), 16565 (3.1), 16566, 16567 (3.10), 16568 (3.14), 16569, 16570 (3.18), 16571 (3.10), 16572 (3.18), 16711 (3.4), 16746 (1.1), 17145 (3.18), 17156 (3.10), 17164 (3.6), 17195 (3.14), 17883 (3.5), 17902 (3.15), 18128 (3.10), 18234 (3.12), 18810 (3.6), 18812 (3.10), 18845 (1.1), 18871 (3.18), 18877 (3.1), 18879 (3.18), 18883 (3.14), 18894, 18895 (3.18), 18941 (1.1), 18956 (3.18), 19377 (3.12), 19388 (2.1), 20020 (3.6), 20072 (1.1), 20280 (3.18), 20331 (3.5), 21104 (1.1), 21553 (3.12), 21898 (1.1), 61902 (3.6), s.n. ALCB 2777, ALCB 104831, ALCB 104833 (3.3), s.n. ALCB 61902 (3.6), s.n. ALCB 35942, UEC 104582 (3.10), s.n. ALCB 41340, ALCB 76767 (3.12), s.n. ALCB 104832, ALCB 21029, CEPEC 65901, HUEFS 42892 (3.15), s.n. ALCB 35967, CEPEC 68905, CEPEC 77847, HRB 34066, HUEFS 62248, UEC 104581, (3.18); Gusmão, E.F. 513 (3.3); Hage, J.L. 1153 (4.1), 1879 (1.1); Haliomian 837 (3.15); Harley, R.M. 14257 (3.6), 15920 (3.6), 17138 (3.7), 17738 (3.7), 18340 (3.9), 18672 (3.6), 20642 (3.6), 21060 (3.6), 21118 (3.1), 21296 (3.18), 21688 (1.1), 21761 (3.18), 21938 (3.18), 24333 (1.1), 26061 (1.1), 26948 (3.14), 27105 (3.14), 27229 (3.1), 27364 (3.14), 27604 (3.18), 50179 (3.14), 50351 (3.1), 53598 (3.10), s.n. ALCB 35985 (3.1), s.n. ALCB 35975, CEPEC 77369, HRB 37053, HUEFS 26124 (3.6), s.n. ALCB 35978 (3.14); Hatschbach, G. 42052 (3.16), 47437 (1.1), 47485 (3.6), 53444, 56811 (1.1), 61995 (3.16), 66092 (3.14), 67884 (1.1); Hind, D.J.N. s.n. ALCB 35971, CEPEC 75607, HUEFS 28824 (1.1), s.n. ALCB 35952 (3.1), s.n. CEPEC 79153 (3.6), s.n. ALCB 35957 ALCB 35972, CEPEC 76158, HUEFS 29513 (3.18); Ibraim, M. 51 (3.1); Irwin, H.S. 14810 (3.16), 14849 (3.10), 14851 (3.1), 31444 (3.16), 32478 (3.1); Jardim, J.G. 569, 1152 (3.8), 2563 (3.14), 2890 (2.1), 3653 (3.18), 4077, 5423 (2.1); Jesus, J.A. 616 (3.2); Jesus, N.G. 820, 821, 823, 824 (3.12), 825 (3.5), 1576, 1693 (1.1), s.n. HUEFS 42911, HUESC 3200, HUESC 7737 (3.12); Jost, T. 268 (2.1), 344 (3.12), 641 (3.2); Labouriau 855 (3.3); Lambert, S.M. 22 (3.6); Leonel, C. 9 (1.1); Lima, D.P. 12762 (3.12); Lima, J. s.n. ALCB 61467 (3.15); Lima, J.C.A. 191 (3.12); Lima, L.C.L. 8 (3.1), s.n. HUEFS 34020 (3.12); Lima, M.P.M. 371 (2.1), 349 (3.12); Loureiro, D.M. 83 (3.18), 302 (3.10), 508 (1.1), 541 (3.5), 630 (3.6); Lordêlo, R.P. 24/65 (3.2); Lorenzi, H. s.n. UEC 104358 (3.8); Luceño, M. s.n. UFP 14170 (3.3); Luschnath, B. 1132 (3.12); Machado, M. 70 (3.10); Marquete, R. 2068 (2.1); Matos, E.N. 590 (3.11), 742 (2.1), 1002 (1.1), 1013 (3.12), 1469 (1.1), 1487 (2.1), 1540 (3.12), 3460 (1.1), 3422 (3.11), 3445 (2.1); Mayworm, M.A. 37 (3.14); Meireles, J.E. 436 (3.3); Melo, E. 3249 (3.10), 5491 (3.6), 8027,8044 (3.3), 8174 (3.16), 8297 (3.10), 8356 (3.18); Mello-Silva, R. 2766 (1.1); Mendonça, R.C. 1485 (3.16), 1503 (1.1), 1551 (3.5), 3225 (3.5), 4265 (3.10), 4580 (3.5); Menezes, C.M. 203 (3.15), 278 (1.1); Miranda, A.M. 3746 (3.10), 5782 (3.5), 5861 (3.15), 6526 (3.12); Miranda, E.B. 772 (3.18); Monteiro, M.T. 23620 (3.7); Moreira, M.L. 4 (3.5); Mori, S.A. 9677 (2.1), 12107 (3.7), 13334 (3.18), 13817 (3.12), 14085 (3.3), 14191 (1.1); Nascimento, A.F.S. 193 (3.15), 263 (3.2); Nascimento, C.B. 10 (3.3); Nascimento, F.H.F. 306 (3.4), 334 (3.4), 351 (3.14), 418 (1.1), Neri, J. 2, 3, 4 (1.1), 49 (3.6), 62, 64, 67, 72, 80, 83 (1.1); Neves, M.F. 178 (3.12); Neves, S.P.S. 373, 402 (3.18); Noblick, L.R. 1270 (3.3), 2181 (3.15), 2229 (3.15), 3417 (3.3), 4451 (3.15), 4990 (3.3); Nunes, L. 10, 10A (3.15); Nunes, T.S. 252 (3.14), 1635 (3.16); Ogasawara, H.A. 145 (3.10); Oliveira, D. s.n. ALCB 109752 (3.3); Oliveira, M. 3037, 3059 (3.3), 3060, 3295 (1.1); Oliveira, P.P. 11 (3.15); Orlandi, R.P. 167 (3.17); Paixão, J.L. 32 (1.1); Passos-Júnior, L.A. 285 (1.1); Passos, L. 373 (3.5), s.n. ALCB 35983, CEPEC 74414, HUEFS 62669 (3.6), s.n. ALCB 35964, CEPEC 77835, HUEFS 62668 (3.10); Pereira, A. 4 (3.12); Pereira, B.A.S. 1614 (3.10); Pigozzo, C.M. 68 (3.6); Pinto, G.C. P. 9 (3.12), 29, 36 (3.15), 150 (3.18), 287 (3.15), 289 (3.3), s.n. ALCB 8971 (3.11); Pirani, J.R. CFCR 1615 (1.1); Plowman, T. 12775 (3.3); Popovkin, A.V. 201, 202 (3.12), 501 (1.1), 588 (3.15), 779, 781 (2.1), 801 (3.15), 845 (3.12), 871 (1.1), 1030 (3.15); Porto, P.C. 1337 (3.15); Prates, A.R. 22, 151, 235 (2.1); Proença, C. 320 (3.14), 1753 (3.16); Queires, L.C. 127 (1.1); Queiroz, E.P. 904 (3.12), 1275, 1366 (3.3), 1443, 1444, 2114 (3.15), 2189 (1.1), 2624, 2670 (3.3), 2692 (3.12), 2806 (1.1), 2834 (3.18), 3002 (2.1), 3097, 3185 (3.10), 3522 (1.1), 3939 (3.18), 4834 (3.14), 4835 (3.5); Queiroz, L.P. 510 (3.3), 861 (3.15), 1407 (3.3), 1412 (3.15), 2012 (3.5), 2033 (3.10), 2037, 2076 (3.5), 2492 (3.3), 5687 (3.10), 6072 (3.14), 6107 (3.18), 7123 (3.14), 12954 (3.2), 13594 (3.6), s.n. ALCB 19421 (3.15); Rapini, A. 1435 (3.10), 2014 (3.14), 2017 (3.16); Ravice, J.M. s.n. ALCB 26392 (3.3); Rebouças, P.o. 33 (3.15); Reis, S. 149 (3.5); Rezende, A.V. 7, 48 (3.5), 103 (3.10); Ribeiro, A.J. 81 (3.3); Ribeiro, E. s.n. ALCB 55233 (3.12); Ribeiro-Filho, A.A. 226, 244 (3.6); Ribeiro, P.L. 253 (3.10); Ribeiro, R. 345 (3.3); Riedel 114 (3.6); Rodart, A. s.n. ALCB 57991(3.3); Roque, N. 850, 929 (3.10), 1066, 1068, 1436, 1449, 1580, 1967, 1977 (3.6), 2753 (3.12), 2818 (3.6), 3830 (3.1), s.n. ALCB 61417 (3.6); Romero, R. 5817 (3.6); Saar, E. s.n. CEPEC 74864, s.n. ALCB 35980, HUEFS 62662 (1.1); Sacramento, A.C. 645 (3.14); Saddi, N. 3 (3.3), 4 (3.12), 5 (3.15), 6, 7 (3.12), 20 , 21 (3.7), 22 (3.3), 23 (3.15), 24 (3.3), 25 (3.15), 26 (3.12); Salimena-Pires, F.R. s.n. ALCB 35998, HUEFS 63649 (3.6); Santana, D.L. 180, 364 (3.12), 448 (3.5); Santana, W. ALCB 9227 (3.3); Sant'Ana, S.C. 284 (3.12); Santos, A.P.B. 44 (3.3), 45 (3.15), 46 (1.1), 47, 48 (3.11), 49 (3.12), 51 (3.11), 54 (3.7), 55 (3.8), 56 (3.17); Santos, G.Q. 07 (3.6); Santos, R.B. 37, 43 (1.1); Santos, T.R. HUEFS 63319 (3.6); Santos, T.S. 1069, 1113 (2.1), 1608 (1.1), 2416 (2.1), 2588 (3.2), 2794 (2.1), 2894 (3.12), 2979 (3.7), 3924 (4.1), 4483,4577 (1.1), 4581 , 4583 (3.7), 4586 (1.1), s.n. CEPEC 92579, HUEFS 60177, HUESC 5930 (1.1); Scariot, A.O. 457 (3.5), 529 (3.10), 530 (3.5); Searalino, L. ALCB 27415 (3.15); Serrão Neto, A.C. 1, 2,3 (1.1); Silva-Castro, M.M. 1063 (3.18), 1400 (3.10); Silva, F.O. 107 (3.15), s.n. ALCB 
89181 (3.1); Silva, G.P. 3690 (3.18); Silva, L.A.M. 1235 (3.6), 2616 (2.1), 2701 (3.11), 2781 (3.6), 3078,5234 (3.11); Silva, L.B. 12 (3.3); Silva, M.A. 1372 (3.10), 1448 (3.1); Silva, M.M. 112 (3.6); Silva, S.B. 381 (3.10); Silva, U.C.S. 171 (3.3); Simões, A.O. 1132 (3.10); Soeiro, R. 9 (3.3); Sousa, J.P. s.n. ALCB 17660 (3.15); Souza, C.S. 34347 (3.3); Souza, E.R. 443 (3.14); Souza-Silva, R.F. 240 (3.16); Stannard, B. 52751, s.n. CEPEC 92291, CEPEC 92288, HUEFS 52069, HUEFS 52048 (3.6), s.n. ALCB 35979, ALCB 35981, CEPEC 79289, HUEFS 62663, HUEFS 62244 (3.18); Stapf, M.N.S. 327 (2.1); Stradmann, M.T.S. 53 (1.1), 563 (3.6), 894 (3.18); Sucre, D. 11199 (3.15); Thomas, W.W. 9858 (2.1); Trad, R.J. 67 (3.18), 69 (3.5), 70, 71, 72 (3.18), 73 (3.10), 74 (3.18), 75 (3.10); 136, 137, 138 (3.8); Valeriano, A. s.n. ALCB 2782, HUEFS 15476 (3.3); Van den Berg, C. 1713, 1716 (1.1); Viana, B.F. 7 (3.3); Vieira, R.F. 1106 (3.18), 1162 (3.14); Vieira, S.S. 6 (3.3); Viollati, L.G. 233 (3.16); Walter, B.M.T. 293 (3.14), 479, 2888 (3.5), 4893 (3.10); Xavier, A.B. 118 (3.5), 137, 187 (3.10); Yoshida-Arns, K. s.n. UFP 60876 (3.14), s.n. UFP 61398, UFP 61614 (3.5); Zehutner 503 (3.5). 